\title{
BITWA POD KUMANOVEM (23-24 PAŹDZIERNIKA 1912 ROKU) SIŁY ZBROJNE STRON, DZIAŁANIA OPERACYJNE, KONSEKWENCJE MILITARNE I POLITYCZNE
}

\author{
DARIUSZ WYBRANOWSKI
}

\begin{abstract}
Dariusz Wybranowski, Bitwa pod Kumanovem (23- 24 października 1912 roku). Sity zbrojne stron, działania operacyjne, konsekwencje militarne i polityczne (The battle of Kumanovo (23-24 October 1912). The armed forces of the parties, operations, military and political consequences).
\end{abstract}

Balcanica Posnaniensia. Acta et studia, XX, Poznań 2013, Wydawnictwo Instytutu Historii UAM, pp. 137-179, ISBN 978-83-63047-36-1, ISSN 0239-4278. Polish text with a summary in English.

Dariusz Wybranowski, Uniwersytet Szczeciński, Instytut Politologii i Europeistyki, ul. Krakowska 17, 71-017 Szczecin.

Temat udziału Serbii w I wojnie bałkańskiej i bitwy pod Kumanovem znalazł odbicie w licznych publikacjach historiografii serbskiej ${ }^{1}$, a także zachodniej (zwłaszcza anglojęzycznej) dotyczącej wojen bałkańskich, lub samej tylko I wojny bałkańskiej$^{2}$. Problem ten został natomiast całkowicie pominięty w kilku syntezach dziejów

${ }^{1}$ Por. m.in. Prvi Balkanski Rat. Okrugli sto povodom 75. Godišnjici 1912-1987, 28 i 29. Oktobar 1987/La premiere guerre balkanique. Table ronde consacree au 75me Anniversaire 1912-1987. Les 28 et 29 octobre 1987, urednik. V. Stojančević, Beograd 1991; Prvi balkanski rat 1912/1913. godine. Društveni i civilizacijni smisao (Povodom stogodišnjice oslobođenja Stare Srbije i Makedonije), urednik A. Rastović, Niš 2013. Por. także m.in. zbiór relacji i wspomnień świadków bitwy pod Kumanovem i felietony na jej temat, Vitezovi Kumanovske bitke, http://www.novosti.rs/dodatni_sadrzaj/fejltoni120.html?item_id=401; Ž. Stanisavljević, Kumanovska bitka, Beograd 1961; Z. M. Jovanović, Zebrnjak u traganja za porekama jednog spomenika, ili o kultury sećanja kod Srba, Beograd 2004; P. Opačić, Kumanovska bitka, Beograd 2005; N. J. Popović, O reviziji i zaborava, http://www.rts.rs/page/rts/sr/Dijaspora/story/ 1526/ Srbija+na+veci/1198316/O+reviziji+i+ zaborava. html; A. Andrić, Istorija Srba, Beograd 2012; Boj iznad Vekova. Sto godina od kumanovske bitke, Beograd 2012. Jednym z ciekawszych studiów problemu dotyczących wysiłku zbrojnego Serbii i Czarnogóry w wojnach bałkańskich, w tym także dość dokładnego opisu bitwy pod Kumanovem, jest praca kilku autorów serbskich, por. B. Ratković, M. Đurišić, S. Skoko, Srbija i Crna Gora u Balkanskim ratovima 1912- 1913, Beograd 1972; A. Jovičić, Balkanski ratovi 1912/1913 godine, Beograd 2006.

2 Por. F. Immanuel, Der Balkankrieg 1912, Berlin 1913; C. Campbell, The Balkan War drama, McBride 1913; C. Ross, Im Balkankrieg, M. Mörikes Verlag 1913; R.C. Hall, The Balkan Wars 1912 -1913: Prelude to the First World War, Routledge 2000; A. Gerolymatos, The Balkan Wars. Conquest and the Revolution from the Ottoman Era to the Twentieth Century and Beyond, Basic Books 2002; 
Bałkanów w XX wieku, przetłumaczonych w ostatnich latach na język polski ${ }^{3}$. Jedynie w opublikowanej niedawno po polsku syntezie dziejów Imperium Osmańskiego, autorstwa Stanforda J. Shawa i Ezela K. Shawa, znalazło się wspomnienie o bitwie ${ }^{4}$.

W polskiej historiografii informacje na ten temat można znaleźć w kilku publikacjach wydanych przed II wojną światową, natomiast w literaturze powojennej bitwa kumanovska była na ogół krótko wspominana, jako jeden z epizodów I wojny bałkańskiej $^{5}$. Nieco więcej na temat tej bitwy można znaleźć w książce Jarosława Rubachy Bułgarski sen o Bizancjum. Polityka zagraniczna Bułgarii w latach 1878- 1913, starcie to zostało omówione jednakże w kontekście udziału bułgarskiej 7. Dywizji Rilskiej6 . W wydanej kilka lat temu, popularnonaukowej syntezie I wojny bałkańskiej, autorstwa Roberta Rabki zostały wprawdzie przedstawione armie stron konfliktu, w tym serbska, jednak autor skupił się niemal wyłącznie na działaniach armii bułgarskiej na froncie trackim ${ }^{7}$. I i II wojną bałkańska, a zwłaszcza trackim teatrem wojennym zajął się także ostatnio Tadeusz Czekalski ${ }^{8}$. Więcej informacji wnieśli do poznania przebiegu tej wielkiej bitwy (jak również dalszego ciąu serbskich działań militarnych w 1912 r.) Tadeusz Rawski i ostatnio Mirosław Dymarski. Z kolei Paweł Michalak

E. J. Erickson, Defeat in Detail. The Ottoman Army in the Balkans, 1912- 1913, London 2003; J. G. Schurman, The Balkan Wars 1912- 1913, New York 2005; A. Vachkov, The Balkan War 1912- 1913, Sofia 2005; C. S. Ford, The Balkan Wars, Being a Series of Lectures Delivered at the Army Since School, Fort Leavenworth, Kansas 2010; I. Despot, The Balkan Wars in the Eye of Warring Press, Bloomington 2012.

${ }^{3}$ Por. B. Jelavich, Historia Bałkanów, T. 2: Wiek XX, Kraków 2006, s. 111- 113; S. K. Pavlowitch, Historia Bałkanów (1804- 1945), Warszawa 2009, s. 239.

4 Por. S. J. Shaw, E. K. Shaw, Historia Imperium Osmańskiego i Republiki Tureckiej, t. 2 (1808-1975), Warszawa 2012, s. 450- 451.

${ }^{5}$ Por. m.in. B. Koskowski, Ostatni rozbiór Turcji. Rozkład państwa tureckiego w Europie. Polityka europejska względem Turcji-czem jest Turcja Azjatycka?, Warszawa- Łódź- Kraków 1915; J. Dąbrowski, Wielka Wojna 1914- 1918, [w:] Wielka Historia Powszechna, Warszawa 1937, s. 38; J. Pajewski, Historia powszechna 1871- 1918, Warszawa 1978, s. 310; J. Reychman, Historia Turcji, Wrocław 1973, s. 275; T. Wituch wspomniał w opisie serbskich działań I wojny bałkańskiej jedynie o zajęciu przez Serbów Skopje, por. idem: Tureckie przemiany. Dzieje Turcji 1878- 1923, Warszawa 1980, s. 188. Podobnie też problem ujęli A. Giza, K. Filipow, Wojny batkańskie 1912- 1913. Aspekty polityczne i militarne (poczatki niewoli Bułgarów w Macedonii Egejskiej i Wardarskiej, Białystok 2002, s. 55. Kwestia działań wojennych na obszarze Macedonii Wardarskiej i samej bitwy kumanovskiej została pominięta w syntezie dziejów Bałkanów w XX wieku M. Tantego, por idem: Bałkany w XX wieku, Warszawa 2003, s. 91-92. Bardzo krótko o fakcie bitwy pod Kumanovem wspominają natomiast T. Wasilewski, W. Felczak, Historia Jugosławii, Wrocław 1985, s. 400; A. Giza, Państwa bałkańskie wobec kwestii macedońskiej w latach 1878- 1918, Szczecin 1996, s. 109; A. Giza, K. Filipow, op. cit., s. 55; W. Walkiewicz, Jugosławia. Byt wspólny i rozpad, seria: Historia państw świata w XX wieku, Warszawa 2000, s. 17; J. Skowronek, M. Tanty, T. Wasilewski, Historia Stowian Poludniowych i Zachodnich, Warszawa 2005, s. 447- 448; A. Malinowski, Kwestia macedońska w Butgarii w latach 1878- 1918, Toruń 2006, s. 133 i D. Kołodziejczyk, Turcja, seria: Historia państw świata w XX wieku, Warszawa 2011, s. 62.

${ }^{6}$ Por. J. Rubacha, Bułgarski sen o Bizancjum. Polityka zagraniczna Butgarii w latach 1878- 1913, Warszawa 2004, s. 254- 255.

7 Por. R. Rabka, Batkany 1912- 1913, Warszawa 2009, s. 60 i n.; 80 i n.

8 Por. T. Czekalski, Bułgaria, seria: Historia państw świata w XX wieku, Warszawa 2010, s. 84- 86.

9 Por. T. Rawski, Państwa Europy Potudniowo- Wschodniej i ich armie podczas wojen bałkańskich w latach 1912-1913, [w:] Państwa narodowe Europy Środkowo- Wschodniej w XX wieku, red. W. Bal- 
zajął się rolą w niej księcia, a potem króla Aleksandra I i genezą powstania swoistego „mitu Kumanova”10. Wart podkreślenia jest też fakt, że w polskich przewodnikach turystycznych po Jugosławii, a obecnie Macedonii, choć pojawiały się informacje o różnych interesujacych obiektach i zabytkach Kumanova, bardzo długo nie było w nich jakichkolwiek informacji o polu bitwy, czy pomniku na wzgórzu Zebrnjak, czyli o tym, co spowodowało, że to średniej wielkości dziś miasto macedońskie weszło do historii $^{11}$. Nie ma też wzmianki o tej bitwie w polskiej syntezie dziejów Macedonii12.

Polityczne, militarne i ideologiczne znaczenie bitwy pod Kumanowem powoduja, że za niezmiernie ważną uznać należy szczegółową analizę przebiegu bitwy i niektórych późniejszych starć zbrojnych, które zadecydowały o wyparciu Turków z terenu Macedonii, z uwzględnieniem potencjału zbrojnego walczących stron i politycznych uwarunkowań I wojny bałkańskiej. Pozostaje kwestia, czy rzeczywiście była ona naprawdę serbską „,decydującą bitwą” i „,największą bitwą”, czy też tak ją potem przedstawiano, a jeśli istotnie tak było, to dlaczego tak się stało. Niniejszy artykuł ma dać odpowiedź na powyższe pytania.

Stworzenie antytureckiej koalicji państw bałkańskich nie było łatwe ze względu na ich sprzeczne interesy odnośnie ziem macedońskich ${ }^{13}$. Najbardziej zainteresowani przyszłą wojną przeciw Turcji byli Bułgarzy, którzy uważali słowiańskich Macedończyków za członków swego narodu i pragnęli ich wyzwolenia, a co za tym idzie włączenia zamieszkałego przez nich terytorium do Bułgarii. Podjęli oni w tym celu akcję propagandową w środowiskach rosyjskich i środkowoeuropejskich neoslawistów na ich zjeździe w Pradze (1908), a przede wszystkim na drugim zjeździe w lipcu 1910 roku w Sofii, angażując dużą liczbę bułgarskich przywódców lokalnych z Macedonii ${ }^{14}$. Idea powołania odrębnej i niezależnej politycznie Macedonii była szczególnie bliska diasporze macedońskiej w Petersburgu, zgrupowanej w krę-

cerak, Łowicz- Warszawa 2000, s. 85; M. Dymarski, Konflikty na Bałkanach w okresie kształtowania sie państw narodowych w XIX i na poczatku XX wieku, Wrocław 2010, s. 248- 250.

${ }^{10}$ P. Michalak, Bitwa pod Kumanovem na tamach gazety „Politika”- mit umacniajacy pozycję politycznq króla Aleksandra I Karadjordjevicia, „Balcanica Posnaniensia. Acta et Studia”, t. XIX, 2012, s. 170 .

11 Por. M. Krukowska, Jugosławia, Warszawa 1985, s. 141 (tu Kumanovo jest marginalnie wspomniane tylko jako jedno z większych miast kraju i lokalizacja fabryki tytoniu); Bałkany. Bośnia i Hercegowina, Serbia, Macedonia, Albania, praca zbiorowa, Kraków 2005, s. 194- 195. Dopiero w ostatnich latach, w kolejnej edycji przewodnika znalazła się bardzo krótka wzmianka o Kumanovie jako „miejscu bitwy z czasów I wojny bałkańskiej”. Por. S. Adamczak, K. Firlej- Adamczak, K. Bzowski, Ł. Gołębiowski, Czarnogóra, Serbia, Macedonia, Kosowo i Albania, Bielsko- Biała 2011, s. 416.

${ }^{12}$ Irena Stawowy- Kawka omówiła plany podziału Macedonii, między Grecję, Serbię i Bułgarię i ich polityczne aspekty oraz sam fakt zajęcia przez Serbów Skopje i Bitoli. Por. I. Stawowy- Kawka, Historia Macedonii, Wrocław 2000, s. 167- 168.

13 Por. I. Stawowy- Kawka, op. cit., s. 164 i n.

14 Szerzej o okolicznościach zwołania zjazdu w Sofii, istniejących wówczas sporach serbsko-bułgarskich o obszar macedoński, zabiegach neoslawistów bułgarskich o poparcie, osobach delegatów i ustaleniach końcowych, por. A. Giza, Państwa bałkańskie, op. cit., s. 120 i n.; A. Giza, K. Filipow, op. cit., s. 49- 51. 
gu Słowiańsko-Macedońskiego Narodowego Towarzystwa Naukowo-Literackiego (zwłaszcza braci Dimitriji i Nade Čupovskich) ${ }^{15}$.

Było też oczywiste, że w politycznych realiach Bałkanów na początku XX wieku, każda koalicja państw bez Turcji może być skierowana tylko przeciw niej i w nadziei na ewentualne rewindykacje terytorialne jej kosztem ${ }^{16}$. Bułgarzy nie byli, bowiem, zainteresowani jakąkolwiek wojną przeciw Austro-Węgrom, z którymi nie mieli sprzecznych interesów. Jedynie perspektywą nowych zdobyczy kosztem Turcji, były zainteresowane praktycznie wszystkie państwa bałkańskie, tj. Serbia, Bułgaria, Grecja i Czarnogóra ${ }^{17}$.

Przyspieszenie formowania się sojuszu serbsko-bułgarskiego nastapiło wiosną 1911 roku, gdy premierem Bułgarii został Iwan Geszow - zwolennik idei sojuszu bałkańskiego o orientacji prorosyjskiej. W kwietniu tego roku propozycję daleko idącej współpracy złożył rządowi bułgarskiemu minister spraw zagranicznych Serbii, Milovan Milovanović. Początkowo została ona odrzucona, ale wybuch wojny włosko-tureckiej w Afryce Północnej skłonił we wrześniu Bułgarów do jej przyjęcia ${ }^{18}$.

Utworzenie efektywnej koalicji przeciw Turcji Osmańskiej wymagało ustaleń między Serbią a Bułgarią w sprawie przyszłego statusu ziem macedońskich. Polityków z Sofii najbardziej interesowała całkowita inkorporacja spornego obszaru, traktowanego jak ,historyczne ziemie bułgarskie”. To jednak nie było możliwe z uwagi na roszczenia Serbii, która również odwoływała się do swych historycznych granic. Kluczowym elementem przyszłego sojuszu bałkańskiego, czy swego rodzaju „ligi bałkańskiej”, stał się układ z 13 marca 1912 roku zawarty między Serbią a Bułgarią, uzupełniony o podpisaną 12 maja tego roku konwencję wojskową. Konwencja ta zobowiązywała Serbię do wystawienia armii w liczbie 100 - 150 tysięcy żołnierzy, a Bułgarię 200 tysięcy wojska ${ }^{19}$. Ustalono też przyszły podział zdobyczy po pokonaniu Turcji. Serbii miały przypaść obszary Sandżaku Novopazarskiego i tzw. Starej Serbii (tj. okolic Raški w południowej części Sandżaku i znacznej części Kosowa) - terytoriów uznanych przez serbskich działaczy narodowych w drugiej połowie XIX wieku za kolebkę serbskiej państwowości ${ }^{20}$. Bułgarzy chcieli natomiast

15 Obszernie na ten temat ostatnio por. L. Moroz-Grzelak, Nadzieje i stracone złudzenia. Wojny batkańskie w świetle tekstów Dimitriji Čupovskiego i Krste P. Misirkova, „Balcanica Posnaniensia”, t. XIX, 2012, s. 297- 307.

${ }^{16}$ A. Giza, K. Filipow, op. cit., s. 52.

${ }^{17}$ Ibidem, s. 52.

18 Por. J. Skowronek, M. Tanty, T. Wasilewski, op. cit., s. 443.

${ }^{19} \mathrm{Z}$ bogatej literatury problemu na temat genezy sojuszu bałkańskiego, zwanego niekiedy „ligą bałkańską", poszczególnych sojuszy i układów zawieranych przez Serbię i Bułgarię, Grecję i Czarnogórę, por. m.in. J. Dąbrowski, op. cit., s. 36- 38; W. Felczak, T. Wasilewski, op. cit., s. 399- 400; I. StawowyKawka, op. cit., s. 165- 167; T. Rawski, op. cit., s. 80- 81; J. Skowronek, M. Tanty, T. Wasilewski, op. cit., s. 443-446; A. Malinowski, op. cit., s. 122- 126; S. K. Pavlowitch, op. cit., s. 238- 239; T. Czekalski, op. cit., s. 82- 84; M. Dymarski, op. cit., s. 235- 239; J. Rubacha, Wielkie mocarstwa europejskie wobec wojen batkańskich 1912- 1913, „Balcanica Posnaniensia. Acta et studia”, t. XIX, 2012, s. 213.

${ }^{20} \mathrm{O}$ tej kwestii, por. szerzej ostatnio W. Szczepański, Belgrad odkrywa Kosowo. U źródel ustanowienia Kosowa centralnym punktem odniesienia polityki serbskiej (ostatnie ćwierćwiecze XIX stulecia), 
zająć Trację Wschodnią z Adrianopolem, Macedonię Egejską z Salonikami, Kavalę i Dedeagacz (tur. Dedeağaç) nad Morzem Egejskim. Natomiast obszar Macedonii między Starą Płaniną, Rodopami i Ochrydem miał uzyskać autonomię ${ }^{21}$, gdyby jednak ta okazała się niemożliwa, to 2/3 ziem Macedonii Wardarskiej z Velesem, Štipem, Monastirem (dziś Bitolą) i Ochrydem mieli inkorporować Bułgarzy, zaś pozostałe 1/3 ze Skopje, Tetovem, Kumanovem i Debarem miało stanowić tzw. strefę sporną do przyszłego podziału między Serbię i Bułgarię. Obszar ten miałby w przyszłości przypaść albo jednej ze stron, albo ulec podziałowi między oba kraje ${ }^{22}$. Miałby o tym zadecydować po zakończeniu wojny z Turcją arbitraż cara Rosji, Mikołaja $\mathrm{II}^{23}$. Grecy natomiast uzgodnili z Bułgarami, że przejmą te ziemie, które uda im się zająć w toku wojny, najbardziej jednak zależało im na części Macedonii Egejskiej z Salonikami²4, co musiało doprowadzić w przyszłości do ostrego zatargu z Bułgarią.

Dla Królestwa Serbii, jako kraju śródlądowego, kwestią zasadniczą stało się uzyskanie dostępu terytorialnego do Adriatyku, stąd też pertraktacje dotyczyły ewentualnych nabytków serbskich na terenie Albanii a zwłaszcza uzyskanie Dracza (alb. Dürres). By przyspieszyć powstawanie sojuszu bałkańskiego między jego wszystkimi kontrahentami ustalono, że szczegółowe porozumienia w sprawie granic zostaną zawarte w okresie późniejszym (tj. zapewne po wojnie). Ostatnim elementem świeżo powstałego sojuszu bałkańskiego stał się traktat serbsko- czarnogórski podpisany 27 września 1912 roku $^{25}$.

\section{PRZEMIANY W UZBROJENIU I WYPOSAŻENIU SIŁ ZBROJNYCH NA POCZĄTKU XX WIEKU}

W drugiej połowie XIX i na początku XX wieku nastąpiło rozpowszechnienie się i stała modernizacja broni palnej, w tym różnego rodzaju wielostrzałowych rewolwerów i karabinów powtarzalnych ${ }^{26}$. Ogromnym wręcz postępem była szybkostrzel-

[w:] Mity historyczno- polityczne- wyobrażenia zbiorowe- polityka historyczna. Studia i materiaty, red. E. Ponczek, A. Sepkowski i M. Rekść, Toruń 2013, t. III, s. 266 i n.

21 J. Skowronek, M. Tanty, T. Wasilewski, op. cit., s 444.

22 Por. m.in. H. Batowski, Państwa bałkańskie 1878- 1923. Zarys historii dyplomatycznej i rozwoju terytorialnego, Kraków 1938, s. 182- 183; I. Stawowy- Kawka, op. cit., s. 166; A. Giza, K. Filipow, op. cit., s. 52 i w ostatnich latach A. Malinowski, op. cit., s. 123- 124.

23 Por. A. Giza, Ziemie macedońskie na przełomie XIX i XX wieku, Szczecin 1996, s. 116. Szerzej na temat roli Rosji w kształtowaniu sytuacji politycznej na Bałkanach przed i w trakcie obu wojen bałkańskich, por. m.in. M. Tanty, Rosja wobec wojen batkańskich 1912- 1913 roku, Warszawa 1970, s. 90 i n.; J. R. Budziński, Polityka zagraniczna Rosji 1907- 1914, Toruń 2000, s. 114 i n.; J. Rubacha, Butgarski sen, op. cit., s. 155 i n.; idem: Wielkie mocarstwa, op. cit., s. 210- 213.

24 J. Skowronek, M. Tanty, T. Wasilewski, op. cit., s 445.

25 Por. m.in. H. Batowski, Podstawy sojuszu bałkańskiego 1912 r. Studium z historii dyplomatycznej 1806- 1912, Kraków 1939, s. 123; A. Giza, K. Filipow, op. cit., s. 53; J. Skowronek, M. Tanty, T. Wasilewski, op. cit., s. 445; M. Dymarski, Konflikty na Bałkanach, op. cit., s. 238- 239.

26 Szerzej na temat typów rewolwerów i karabinów powtarzalnych (zwłaszcza Enfield, Lebel i Mauser) stosowanych i modernizowanych od przełomu XIX i XX wieku oraz ewolucji tego typu bro- 
na broń samopowtarzalna w rodzaju karabinów maszynowych (km-ów). Szczególnie popularną konstrukcją był zaprojektowany w Wielkiej Brytanii karabin maszynowy Maxima, który doczekał się w różnych państwach licznych licencji i ulepszeń technicznych ${ }^{27}$. Bardzo szybko km-y zastąpiły przestarzałe już i bardzo podatne na zacięcia kartaczownice (typu Gardner, Gatling, Nordenfelt i in.), będące swoistym prototypem karabinu maszynowego ${ }^{28}$. Z uwagi na niespotykaną do tej pory szybkostrzelność, donośność, celność i siłę ognia, km-y stanowiły swego rodzaju rewolucję na polu walki, zwiększając w sposób nieporównywalny liczbę zabitych i rannych żołnierzy przeciwnika. Pociski łączone z łuskami (podobnie jak w zwykłym karabinie i w rewolwerach), ładowane do taśm, siały śmierć i zniszczenie. Skok techniczny i jakościowy dokonał się także w artylerii, zwłaszcza polowej, która ładowana w sposób odtylcowy, ułatwiła załadowanie pocisków, zwiększyła też znacznie swoją szybkostrzelność i zasięg rażenia ${ }^{29}$. Początek XX wieku przyniósł też zmiany w wyglądzie oficerów i żołnierzy armii państw bałkańskich za sprawą stosowania ubiorów polowych, które bardziej pozwalały się wtopić wyglądem w otoczenie, aniżeli dawniej stosowane barwne mundury, szczególnie oficerskie ${ }^{30}$.

\section{STOSUNEK SIŁ I UZBROJENIE ARMII TURECKIEJ I ARMII SERBSKIEJ}

\subsection{ARMIA SERBSKA I JEJ STRUKTURA WEWNĘTRZNA}

U schyłku XIX wieku armia Serbii uczestniczyła w kilku znaczących konfliktach militarnych (1875- 1876, 1877-1878 i 1885), które pozwoliły kadrze oficerskiej i żołnierzom na zdobycie niezbędnego doświadczenia bojowego oraz pewnej wiedzy na temat funkcjonowania ówczesnych sił osmańskich (w 1885 roku również armii bułgarskiej) w warunkach bojowych. Umożliwiło to również, oprócz prowadzonych działań wywiadowczych, rozpoznanie realiów terenowych przyszłego pola walki (zwłaszcza obszaru Macedonii Wardarskiej, nazywanej też „Serbią Południową” - Južna Srbija).

ni strzeleckiej, por. zwłaszcza Major F. Myatt MC, Broń strzelecka XIX wieku, Warszawa 1995, s. 88 i n.; Ch. Mc Nab, Broń strzelecka XX stulecia, Warszawa 2002, s. 14 i n.

$27 \mathrm{Na}$ temat działalności Hirama Maxima, stosowanych typów broni maszynowej i rozwiązań technicznych z przełomu XIX- XX wieku, por. R. Ford, Historia broni maszynowej od roku 1860 do czasów współczesnych, Warszawa 1999, s. 19 i n.; Ch. Mc Nab, op. cit., s. 205. Innymi typami ciężkiego karabinu maszynowego zastosowanymi bojowo na początku XX wieku w Europie były m.in. Parabellum -Maschinengewehr 14, francuskie M07 T17 St Etienne, Hotchkiss Modele 1895 i włoskie Perino M1913 i Fiat Revelli Modello 1914 oraz lekkie karabiny maszynowe: francuski typu Lebel, brytyjski Lewis i niemiecki Bergmann MG 15nA. Por. R. Ford, op. cit., s. 30 i n.; Major F. Myatt, op. cit., s. 187 i n.

28 . R. Ford, op. cit., s. 7- 18; Major F. Myatt, op. cit., s. 180- 186.

29 Por. M.E. Haskew, Artyleria. Artyleria od I wojny światowej do współczesności, Warszawa 2010, s. $21-25$.

30 Por. P.S. Jovett, Armies of the Balkan Wars 1912- 1913. The priming chargé for the Great War, Osprey Publishing Ltd 2011, s. 36 i n. 
U niektórych ze swych przeciwników, Serbowie zdobyli sobie opinię „twardych" i „walecznych” żołnierzy, jednak oni sami, mimo dostrzegania pewnych zalet bojowych przeciwnika, uważali zwłaszcza Albańczyków, za swych historycznych wrogów, których trzeba bezwzględnie zwalczać31. W roku 1906 i w latach następnych zaczęto wdrażać forsowny proces przezbrajania armii serbskiej, stąd też u progu I wojny bałkańskiej była ona w miarę dobrze wyposażona i wyszkolona w stosunku do sił osmańskich, a także innych armii bałkańskich ${ }^{32}$.

Obszar Królestwa Serbii wynosił w 1912 roku 48 tysięcy $303 \mathrm{~km}^{233}$, a liczba jej ludności wynosiła około 3 milionów mieszkańców ${ }^{34}$. Pierwotnie siły zbrojne Serbii stanowiło głównie pospolite ruszenie, które dopiero na przełomie XIX i XX wieku przekształciło się w regularną armię ${ }^{35}$. W razie ogłoszenia mobilizacji generalnej do służby formalnie powoływani byli wszyscy mężczyźni w przedziale wiekowym $18-50 / 55 \mathrm{lat}^{36}$. Byli oni podzieleni na 4 grupy wiekowe pod względem powołania: I poziv, obejmował żołnierzy służby czynnej i rezerwistów między 21, a 30 rokiem życia. W 1912 roku owa pierwsza grupa powołania, obejmowała 3700 oficerów i 165 tysięcy pozostałych żołnierzy. Natomiast II poziv stanowili rezerwiści w wieku od 31 do 38 lat. Tworzyło go we wspomnianym roku 1950 oficerów i 86 tysięcy żołnierzy niższych rangą. Obie te grupy tworzyły trzon armii polowej (Narodna Vojska). Natomiast trzecia grupa pod względem powołania (III poziv) zamykała się w przedziale od 39 do 45 lat (1480 oficerów i 46 tysięcy żołnierzy) tworząc serbską obronę terytorialną. Ostatnia, czwarta z grup (Poskana Odbrana) to mężczyźni w wieku od 17 do 20 lat i od 46 do 50/55 lat. Mogli zostać wezwani do służby w ramach obrony terytorialnej i transportowo- zaopatrzeniowej, jak również do innych prac pomocniczych na tyłach w wyjątkowych przypadkach. Ten człon sił zbrojnych stanowił głęboką rezerwę, swego rodzaju armię odwodową „ostatniej szansy”.

Terytorium Serbii było podzielone na 5 okręgów wojskowych noszących nazwy wywodzące się od wielkich rzek i krain - „Dunav”/Dunaj, „Drina”, „Morava”, „Timok" i „Šumadija" ${ }^{77}$. Pod względem formalnym każda z tych jednostek wojskowo-terytorialnych miała sformować po 3 dywizje noszące nazwy okręgów, w których

31 Na temat wzajemnego postrzegania Serbów iAlbańczyków, por. w ostatnich latach: W. Szczepański, Mity i stereotypy. Stosunek elit serbskich do Albańczyków z wilajetu kosowskiego (1878- 1912), „Przegląd Zachodni”, 2007, z. 3; D. Gibas- Krzak, Serbsko albański konflikt o Kosowo w XX wieku. Uwarunkowania-przebieg-konsekwencje, Toruń 2008, s. 26 i n.

32 Por. P.S. Jovett, op. cit., s. 17.

33 Por. T. Rawski, op. cit., s. 79.

34 Ibidem, s. 79.

35 Ibidem, s. 79.

36 Por. ostatnio cenne studium problemu-A. Krzak, I wojna bałkańska-plany wojenne i charakterystyka sit konfliktu [w:] Poznać Bałkany, t. IV. Historia-Polityka-Kultura-Języki, red. K. Taczyńska i A. Twardowska, Toruń 2012, s. 61.

${ }^{37} \mathrm{Na}$ temat organizacji terytorialnej armii Królestwa Serbii, por. S. Mučibabić, Vojna nauka i ratna veština u prvom Balkanskom Ratu, [w:] Prvi Balkanski Rat 1912 godine i kraj osmanskog carstva u Balkana, urednik V. Stojančević, Beograd 2007, s. 107- 108; R. Rabka, op. cit., s. 61; P.S. Jovett, op. cit., s. 17- 18; A. Krzak, op. cit., s. 61. 
zostały uformowane (np. Dywizja Piechoty „Dunav” I poziva - Pešadijska Divizija „Dunav” I poziva). Pewną słabością ówczesnej armii serbskiej był niedostatek odpowiednio wyszkolonych i wykształconych oficerów, których kierowano przede wszystkim do jednostek formowania wg I grupy wiekowej i powołania. Natomiast w siłach II i zwłaszcza III grupy powołania, owe stanowiska, czy obowiązki oficerskie sprawowali niekiedy starsi stopniem podoficerowie, którzy mogli być niskiego urodzenia, lecz posiadali doświadczenie, stosowny autorytet, czy nawet zmysł dowódczy na polu walki i byli na tyle inteligentni, by radzić sobie z kierowaniem żołnierzami. Nazywani byli oni zwyczajowo „starszymi” - starš $i^{38}$.

Największą jednostką operacyjną armii serbskiej była dywizja (divizija) piechoty (pešadijska) lub kawalerii (konjička, kavalerijska). Po mobilizacji armia liczyła 10 dywizji piechoty (5 tzw. ,pierwszej” pod względem powołania pod broń - divizija prvi poziv [dalej I] i 5 drugiej grupy powołania - divizija drugi poziv [dalej II]). Możliwe było dodatkowo sformowanie kolejnych 5 dywizji, złożonych ze wspomnianych rezerwistów, które tworzyłyby treci poziv [III]. W tej kategorii największą jednostką o charakterze samodzielnym był pułk $(p u k)^{39}$.

Kolejnym segmentem armii były 2 samodzielne brygady piechoty (samostalna pešadijska brigada) i jako jedyna większa jednostka jazdy o charakterze operacyjnym, Dywizja Kawalerii (Konjička Divizija), która była złożona z dwóch brygad, a każda z nich zawierała w sobie dwa pułki konne. Inne jednostki to kompania i dwa szwadrony gwardii królewskiej, bateria moździerzy, dwie baterie haubic, a ponadto cztery baterie artylerii fortecznej ${ }^{40}$. Całość sił wspierały dodatkowo ogniem ciężkie i lekkie karabiny maszynowe i działa o różnym kalibrze, o czym niżej. Od 1912 roku armia została wyposażona w mundury polowe w różnych odcieniach zieleni i khaki. Ponadto każdy oficer i żołnierz I i II poziva otrzymywał przydział na komplet umundurowania zimowego, w tym m.in. długi, ocieplony płaszcz, czapkę i stosowne buty. Jednakże jednostki III grupy powołania posiadały zazwyczaj już tylko niektóre elementy ubioru wojskowego ${ }^{41}$.

Kluczową jednostką pod względem taktyczno-operacyjnym była w armii serbskiej dywizja. Każda z dywizji piechoty I poziva była złożona z 4 pułków (każdy z nich liczył 4 bataliony piechoty, kompanię karabinów maszynowych - serb. mitraljezi, tj. 4 sztuki broni), ponadto pułk kawalerii (3 szwadrony), pułk artylerii polowej (9 baterii, tj. 36 dział) ${ }^{42}$. Poza tym, rzeczona dywizja składała się jeszcze z półbatalionu inżynieryjnego, oddziałów saperskich do budowy mostów, zaopatrzenia w amunicję, oddziału łączności (telegraficznej), oddziałów sanitarnych mających na wyposażeniu szpitale polowe i oddziały zaopatrzeniowe (żywność, umundurowanie), służb tyłowych i batalionów rezerwowych ${ }^{43}$. Serbska dywizja I poziva liczyła sobie według

\footnotetext{
38 Por. R. Rabka, op. cit., s. 61.

39 Ibidem, s. 61.

40 Por. A. Krzak, op. cit., s. 62.

41 Szerzej na ten temat, por. P.S. Jovett, op. cit., s. 28, 41.

42 Por. S. Mučibabić, op. cit., s. 108; A. Krzak, op. cit., s. 61.

43 Ibidem.
} 
etatu i według różnych opracowań od 23, 5 tysiąca aż do 28 tysięcy żołnierzy, natomiast dywizja II poziva posiadała 18 tysięcy żołnierzy ${ }^{44}$. Np. P.S. Jovett podaje np., że stan dywizji I poziva liczył sobie aż 23, 5 tysiąca żołnierzy, natomiast etat pułku wynosił aż 4 tysiące 860 żołnierzy, a każdy batalion 1 tysiąc 106 żołnierzy ${ }^{45}$.

Naczelnym wodzem armii Królestwa Serbii był formalnie król Piotr Karađorđević, natomiast faktyczne dowództwo spoczywało w rękach szefa sztabu armii, generała Radomira Putnika (mianowanego po bitwie kumanovskiej marszałkiem polnym - vojvoda $)^{46}$. Poza tym główne siły Serbii były wspomagane przez oddziały partyzanckie - czety, rozlokowane na obszarze Sandżaku Novopazarskiego, Macedonii i Albanii, które oprócz dobrej znajomości terenu, w razie potrzeby dokonywały różnorodnych aktów dywersji na tyłach armii osmańskiej, mogły przerywać jej linie zaopatrzenia lub nawet atakować mniejsze oddziały i posterunki żandarmerii. W przypadku Macedonii, owe kilkunastoosobowe czety były skoncentrowane zwłaszcza na pograniczu serbsko-macedońskim na północy i w zachodniej części tego terytorium ${ }^{47}$. Całość tych nieregularnych jednostek nosiła nazwę Obrony Ludowej (Narodna Odbrana), natomiast główną siłą polityczno-militarną była Wewnętrzna Macedońska Organizacja Rewolucyjna (Vnatrešna Makedonska Revolucionerna Organizacija VMRO), która była skoncentrowana zwłaszcza w Macedonii Egejskiej i w południowo-zachodniej Bułgarii ${ }^{48}$. Po I Wojnie Światowej, w niedalekiej stosunkowo przyszłości, VMRO podjęła walkę z rządem w Atenach, a potem i w Belgradzie, ponadto zaczęła być traktowana jako klasyczna organizacja terrorystyczna ${ }^{49}$.

Dość istotny problem dla badaczy nastręcza liczebność sił zbrojnych Królestwa Serbii. Aleksander Riabinin szacuje je w momencie wybuchu wojny na 163 tysiące wojska, 624 działa i 196 karabinów maszynowych. Andrzej Krzak ustalił liczebność armii serbskiej na 200 - 250 tysięcy ${ }^{50}$, Borislav Ratković, Mitar Đurišić i Savo Skoko na 265 tysięcy ${ }^{51}$, a Mieczysław Tanty, Wacław Felczak, Tadeusz Wasilewski i Mirosław Dymarski na 220 tysięcy żołnierzy ${ }^{52}$, a Tadeusz Rawski aż na 286 tysię-

44 Por. P.S. Jovett, op. cit., s. 18; A. Krzak, op. cit., s. 61.

45 Por. P.S. Jovett, op. cit., s. 18.

46 Por. R.C. Hall, The Balkan, op. cit., s. 45; M. Dymarski, op. cit., s. 248.

47 Por. m.in. A. Giza, Państwa balkańskie, op. cit., s. 107, 16- 117.

48 O początkach macedońskiego ruchu narodowego oraz genezie i działalności VMRO, por. szerzej I. Stawowy- Kawka, op. cit., s. 144 i n.

49 A. Giza, op. cit., s. 55 i n.; T. Czekalski, Bułgaria, op. cit., s. 107- 108.

50 Por. A. Krzak, op. cit., s. 62.

51 Por. B. Ratković, M. Đurišić, S. Skoko, op. cit., s. 27- 28. Według wspomnianych autorów potencjał mobilizacyjny Serbii był obliczany na około 350 tysięcy oficerów i żołnierzy niższych stopniem (co zapewne stanowiło absolutne maksimum, jak na stosunkowo niewielki terytorialnie kraj z kilkumilionową ludnością). Park artyleryjski był obliczany ogółem na 544 działa różnego kalibru, w tym około 370 armat polowych. To wszystko stanowiło w stosunku do innych państw bałkańskich spory stopień militaryzacji i jednocześnie wydatków wojskowych.

52 Dla porównania, najsilniejsza militarnie w sojuszu bałkańskim Bułgaria miała wysłać na front tracki aż 340 tysięcy żołnierzy zgrupowanych w 3 bardzo silne i dobrze uzbrojone armie oraz inne jednostki ochotnicze, złożone m.in. z Macedończyków. Por. T. Wasilewski, M. Tanty, J. Skowronek, op. cit., s. 447; M. Dymarski, op. cit., s 252. 
cy żołnierzy ${ }^{53}$. Osiągnięcie stanu armii podanego przez Tadeusza Rawskiego było jednak zapewne możliwe tylko w przypadku ostatecznej mobilizacji III poziva i być może Poskanej Odbrany.

Całość sił przeznaczonych do działań wojennych tworzyło kilka dużych grup operacyjnych. 1. Armia dowodzona była formalnie przez młodego następcę tronu, księcia Aleksandra Karađorđevicia (1888-1934), faktycznie zaś przez ówczesnego szefa Sztabu Generalnego, generała Radomira Putnika (1847- 1917), jednego z najstarszych i najbardziej doświadczonych pod względem bojowym wyższych oficerów ${ }^{54}$. Istotną rolę odgrywał także szef sztabu 1. Armii, generał Petar Bojović. Ta grupa operacyjna, usytuowana centralnie,-liczyła 126-132 tysiące żołnierzy i znajdowała się w dolinie rzeki Moravy ${ }^{55}$. W jej skład wchodziły: Dywizja Piechoty (dalej DP) „Morava” (I), DP „Drina” (I), DP „Dunav” (I), DP „Dunav” (II), DP „Timok” (II), rolę jednostki szybkiej spełniała samodzielna Dywizja Kawalerii. Ponadto 1. Armia posiadała 148-172 działa, tj. ponad 30\% całości artylerii, jaką dysponowała armia serbska (jeśli przyjąć za wiarygodny ów górny pułap 500 dział) i aż 100 karabinów maszynowych ${ }^{56}$.

Głównym zadaniem 1. Armii było uderzenie z rejonu Vranja na zgrupowanie 3. Armii tureckiej rozlokowane w dolinie Wardaru (tzw. Armia Wardarska) ${ }^{57}$. Natomiast 2. Armia dowodzona przez generała Stepę Stepanovicia i złożona z dwóch dywizji (DP „Timok”(I) oraz bułgarskiej 7. Dywizji Rilskiej generała Georgi Todorowa, łącznie obliczana na 74 tysięcy żołnierzy) tworzyła grupę operacyjną na obszarze pogranicznym południowo- zachodniej Bułgarii koło Kjustendiłu i Dupnicy ${ }^{58}$. Przeznaczono jej uderzenie w prawe skrzydło sił tureckich w rejonie Krivej Palanki (tur. Egri Palanka), a następnie dotarcie na Ovče Polje (tur. Koyun Ovasinda, obszar między obecnymi Sveti Nikole, Velesem i Štipem) i ostatecznie, ewentualne zapobieżenie odwrotowi tureckiemu. Siły 3 . Armii generała Božidara Jankovicia (obliczane na 63 do 76 tysięcy żołnierzy) znajdowały się na zachód od armii księcia Aleksandra na kierunku kosowskim ${ }^{59}$. Tworzyły ją DP „Šumadija” (I), DP „Drina”

53 Por. T. Rawski, op. cit., s. 82.

$54 \mathrm{Na}$ temat Radomira Putnika, weterana wszystkich wojen prowadzonych przez Serbię od 1876 do 1913 przeciw Turcji, Bułgarii (1885), generała i marszałka polnego (vojvody, pierwszego tego stopnia) podczas obu wojen bałkańskich i I wojny światowej, por. L. Popović, M. Miličević, Generali vojske Kneževine i Kraljevine Srbije, Beograd 2003.

55 Por. T. Rawski, op. cit., s. 82; R. Rabka, op. cit., s. 62; M. Dymarski, op. cit., s. 248; P.S. Jovett, op. cit., .s 132 .

56 Por. B. Ratković, M. Đurišić, S. Skoko, op. cit., s. 70.

57 Ibidem, s. 39-40.

58 Božidar Ratković, Mitar Đurišić i Savo Skoko podają liczebność 2. Armii w wysokości aż 74 tysięcy, co nie wydaje się możliwe. Armia ta składała się z dwóch dywizji. Serbska dywizja liczyła od 23 do 27 tysięcy żołnierzy. Dywizja bułgarska mogła liczyć do 30 tysięcy ludzi. Wydaje się, że liczba pomiędzy 50 a 60 tysięcy żołnierzy dla całości sił 2.Armii wydaje się najbardziej prawdopodobna.

59 Tu po raz kolejny występują rozbieżności, co do liczebności poszczególnych armii. T. Rawski wymienia liczbę 63 tysiące żołnierzy w składzie 3. Armii, por. idem, s. 83. Natomiast wspomniani wyżej trzej autorzy serbscy w swej syntezie podają liczbę aż 76 tysięcy. Dość zbliżone dane podaje Philip S. Jovett, tj. 74 tysiące wojska (por. idem, s. 18). 
(II) i DP „Morava” (II). Wojska Jankovicia były podzielone dla lepszego przemieszczania się i szybkości marszu na dwie grupy operacyjne - pierwsza skoncentrowana została w rejonie Toplicy, a druga koło graniczącej z Kosowem Medveđi ${ }^{60}$.

Charakter typowo pomocniczej, czy uzupełniającej operacji na terenie Sandżaku Novopazarskiego i północnego Kosowa, mającej następnie wyjść na lewe skrzydło Armii Wardaru posiadały siły Armii Ibarskiej (23-25 tysięcy żołnierzy) dowodzonej przez generała Mihajlo Živkovicia. Jej podstawą była DP „Šumadija” (II). Skoncentrowana została w rejonie Raški jako osłona prawego skrzydła trzonu głównych sił serbskich - 1 i 3 Armii. Funkcję odwodu strategicznego i zarazem wsparcia Armii Ibarskiej pełniła Samodzielna Brygada „Javor” (12 tysięcy żołnierzy) dowodzona przez generała Milivoje Anđelkovicia ${ }^{61}$.

\subsubsection{Uzbrojenie strzeleckie}

Oficerowie byli wyposażeni w dwa główne typy rewolweru. Powszechnie używanym był rosyjski Nagant M 1891 i znacznie wcześniejszy, M1870 Francotte ${ }^{62}$. Natomiast podoficerowie i zwykli żołnierze posiadali, jako główny element wyposażenia strzeleckiego, różne rodzaje karabinów powtarzalnych, ładowanych odtylcowo. Najbardziej nowoczesnym typem karabinu w armii serbskiej, używanym przez piechotę, kawalerię i inne formacje był Mauser M1910 (kal. $7 \mathrm{~mm}$ ), ale nadal używane były starsze typy - Mausery M1889 i M1889/07 oraz jeszcze wcześniejsze Mauser Koka M 1880s (tych Serbowie posiadali jeszcze około 45 tysięcy) ${ }^{63}$.

Jednostki drugiego rzutu, czy drugiej grupy powołaniowej (II poziva) miały z kolei na wyposażeniu Mausera M 1880/07. Na ogólną liczbę 288 tysięcy karabinów, jakimi dysponowała armia serbska, tak przed wybuchem, jak i w trakcie trwania omawianego konfliktu, Mausery - Koka M1884, tj. broń starszego typu, stanowiły ok. 1/6 $6^{64}$. I wojna bałkańska (1912- 1913) była pierwszym konfliktem europejskim, w którym na tak dużą skalę zaczęto używać broni powtarzalnej, samopowtarzalnej i maszynowej. W jej przededniu, siły serbskie posiadały na wyposażeniu 230 karabinów maszynowych, a podstawowym typem był ciężki karabin maszynowy Maxim DWM $1909^{65}$. Była to broń szczególnie cenna, także z uwagi na bardzo duże zużycie amunicji strzeleckiej, koszt i dość skomplikowaną (jak na tamte czasy) technologię produkcji, czy sposób eksploatacji bojowej, bo na każdy pułk przypadała drużyna lub pluton złożone jedynie z 4 karabinów maszynowych ${ }^{66}$. Spośród sił koalicyjnych po-

\footnotetext{
${ }^{60}$ Por. B. Ratković, M. Đurišić, S. Skoko, op. cit., s. 47- 49

${ }^{61}$ Por. T. Rawski, op. cit., s. 83; B. Ratković, M. Đurišić, S. Skoko, op. cit., s. 47- 49.

62 P.S. Jovett, op. cit., s. 23.

63 Ibidem, s. 23.

${ }^{64}$ Ibidem, s. 24.

65 Ibidem, s. 34.

${ }^{66}$ Por. R. Rabka, op. cit., s. 62.
} 
wstałego sojuszu bałkańskiego, armia Królestwa Serbii była jedną z najlepiej wyposażonych w ten rodzaj uzbrojenia strzeleckiego ${ }^{67}$.

To wszystko jednak generowało ogromne koszty i było ogromnym obciążeniem dla skarbu państwa. Jednakże Serbia od długiego czasu przygotowywała się na wielką wojnę z Turcją. Wydatki na armię i infrastrukturę wojskową pokrywano w znacznym stopniu z bardzo dużych pożyczek zagranicznych. Był to dla Królestwa swoisty priorytet w strukturze budżetu. Od 1862 do 1913 roku Serbia zaciagnę̧ła łącznie 33 kredyty zagraniczne i wewnętrzne. W momencie wybuchu I wojny bałkańskiej pozostało jej jeszcze do spłacenia 10 kredytów na ogromną sumę aż 815, 3 milionów dinarów w złocie. Jednocześnie wraz z wybuchem wojny i raptownym skokiem wydatków, załamały się uzyskiwane wcześniej dochody z podatków. Miesięczne wpływy z tego tytułu wynosiły jeszcze w listopadzie 1911 roku 5,8 miliona dinarów w złocie, natomiast już w tym samym miesiącu 1912 roku jedynie 600 tysięcy. Dochody podatkowe podniosły się wprawdzie w 1913 roku do poziomu 2,9 miliona dinarów, była to jednak tylko połowa wcześniejszych, przedwojennych dochodów, szacowanych na blisko 6 milionów dinarów w złocie ${ }^{68}$. Wiadomo jednak, że prowadzona wojna z reguły generuje dalsze podatki i obciążenia obywateli oraz zmusza państwo do zaciagania nowych kredytów, najczęściej oznacza to pogorszenie ogólnego stanu gospodarczego kraju. Stąd też nawet zwycięstwo w wojnie jest najczęściej bardzo kosztowne.

\subsubsection{Uzbrojenie artyleryjskie}

Zaopatrzenie wojsk serbskich w artylerię, zwłaszcza nowszego typu, było na dość dobrym poziomie, szczególnie w porównaniu do armii osmańskiej. Według różnych danych Serbowie posiadali od 344 do 554 dział różnych kalibrów i typów ${ }^{69}$. W 1906 roku zakupili we Francji aż 184 bardzo nowoczesne, szybkostrzelne armaty Schneidera wz. 1897, kalibru $75 \mathrm{~mm}^{70}$. Również na początku XX wieku serbskiej armii udało się zrealizować zamówienie we Francji na pewną liczbę znacznie starszych

${ }^{67}$ Dla porównania, armia Bułgarii, uważana za najsilniejszą pod względem militarnym (oprócz osmańskiej) na Bałkanach, posiadała na swym wyposażeniu w 1908 roku 144 karabiny maszynowe Maxima M1908, z czego na pułk piechoty przypadały 4 sztuki. Kilka lat później, w 1913 roku liczba karabinów maszynowych uległa wydatnemu zwiększeniu do 233. Grecy posiadali ogółem $84 \mathrm{ckm}$ Maxima i austro- węgierskich Schwarzlose M1907, ponadto pewną liczbę lekkich karabinów maszynowych (zwłaszcza francuskie Chauchaty). Armia Królestwa Czarnogóry będąca najmniejszą liczebnie miała na stanie w 1912 roku tylko 12 karabinów maszynowych Maxima oraz 7 już przestarzałych kartaczownic Nordenfelta. Chcąc zmniejszyć tę bardzo widoczną lukę techniczną i militarną, Czarnogórcy zamówili już w czasie trwania I wojny bałkańskiej dalszych 30 sztuk karabinów maszynowych, jednak dostawa ta nie została zrealizowana. Por. P. S. Jovett, op. cit., s. 34.

68 Por. M. Dymarski, Aspekty ekonomiczne i społeczne wojen bałkańskich 1912- 1913, „Balcanica Posnaniensia. Acta et Studia", t. XIX, 2012, s. 223.

${ }^{69}$ Por. B. Ratković, M. Đurišić, S. Skoko, op. cit., s. 47- 49; J. Rubacha, op. cit., s. 245; P.S. Jovett, op. cit., s. 34; A. Krzak, op. cit., s. 62.

${ }^{70} \mathrm{O}$ tym typie armaty, szerzej por. I. Hogg, Artyleria dwudziestego wieku, Warszawa 2001, s. 16. 
już armat polowych $90 \mathrm{~mm}$ typ M1877 . Mniej korzystnie, podobnie jak i w siłach osmańskich, wyglądało natomiast zaopatrzenie armii serbskiej w armaty i haubice cięższego kalibru. Jedynie 24- 28 haubic miało kaliber $150 \mathrm{~mm}$, a 22 - kaliber $120 \mathrm{~mm}$. Z uwagi na charakter ukształtowania powierzchni kraju i przyszłego teatru wojennego, ważną rolę odgrywały też armaty górskie, których armia serbska posiadała 72 sztuki $^{72}$.

W związku ze stale rosnącą rolą artylerii na polu walki, zwłaszcza cięższego kalibru, konieczne było stopniowe przezbrojenie i uzupełnienie wyposażenia armii o nowsze typy uzbrojenia artyleryjskiego. Trzeba jednak zaznaczyć, że nie tylko podczas wojen bałkańskich, ale także podczas I wojny światowej, a potem w latach 1918-1939 działa różnych typów, mimo długiej metryki sprawowały się jeszcze dość zadowalająco.

\subsection{3. Środki transportu i lotnictwo}

Z uwagi na to, że samochody były stosunkowo nowymi i nielicznymi środkami transportu, transport żołnierzy i sprzętu bazował na wozach z zaprzęgami końskimi, mułach jucznych i na wołach. Te ostatnie były używane zwłaszcza do ciagnięcia dział i jaszczy amunicyjnych po górskich drogach i bezdrożach. Każda z armii państw bałkańskich posiadała znaczną liczbę koni pociągowych, mułów i wołów w swych taborach. Każdy pułk artylerii potrzebował około 400 zwierząt pociagowych używanych do różnego typu transportu ${ }^{73}$. O ile było to możliwe, wykorzystywano też do przewozu wojska i sprzętu kolej żelazną, aczkolwiek gęstość sieci kolejowej i ilość składów pociagów była wówczas ograniczona.

Motoryzacja armii była jeszcze sprawą dosyć odległą. W 1912 roku w całej Serbii było tylko 130 państwowych i prywatnych pojazdów mechanicznych, które zostały zarekwirowane na potrzeby armii ${ }^{74}$. Lotnictwo było rodzajem broni jeszcze nowszym, de facto bronią eksperymentalną i niepozbawioną bardzo licznych usterek i niedoskonałości konstrukcyjnych i technicznych. $Z$ uwagi na to, traktowano je jeszcze z ogromną nieufnością ${ }^{75}$. Na Bałkanach w okresie obu wojen do 1913 roku w użyciu było kilka typów samolotów produkcji francuskiej - jednopłatowe Blériot XI, Nieuport i Deperdussin, ponadto dwupłatowce typu Farman (konstrukcji Maurice'a i Henriego Farmanów). Uzbrojone były w 1-2 karabiny maszynowe, a rolę bomb lotniczych spełniały granaty ręczne zrzucane przez pilotów. Decyzję w sprawie oficjalnego utworzenia sił powietrznych Serbii wydał 24 grudnia 1912 roku niedawno mianowany wówczas marszałek polny Radomir Putnik. Pierwsi piloci byli szkoleni

\footnotetext{
71 Por. P. S. Jovett, op. cit., s. 34- 35.

72 P.S. Jovett pisze o 344 działach serbskich. Natomiast R. Rabka na s. 60 informuje, że w armii serbskiej było ogółem 500 dział, natomiast na s. 62, że posiadała ona 827 dział polowych.

73 Por. P. S. Jovett, op. cit., s. 34.

74 Ibidem.

75 Por. W. Bączkowski, Samoloty I Wojny Światowej, Warszawa 2000, s. 5.
} 
we Francji, a podstawą tworzonych sił powietrznych były najpierw balony i Eskadra Balonowa $^{76}$. Bardzo niewielkie liczebnie i kadrowo lotnictwo (Srpska Avijatika) posiadało w czasie I wojny bałkańskiej jedynie 3 aeroplany, ich stan uległ zwiększeniu dopiero pod koniec II wojny bałkańskiej do 10 sztuk $^{77}$. Pewnym wsparciem byli też piloci rosyjscy, których kilku przyleciało na Bałkany na swych maszynach z Rosji ${ }^{78}$.

\subsection{ARMIA TURECKA, JEJ STRUKTURA I DYSLOKACJA PRZED WOJNA}

Jeśliby oceniać stan i potencjał Turcji tylko na podstawie jej terytorium widocznego na mapie, to teoretycznie była ona mocarstwem. Tuż przed I wojną bałkańską jej obszar wynosił bowiem 1,9 miliona $\mathrm{km}^{2}$ i według szacunków zamieszkiwało na nim około 22- 26 milionów ludności. Z tego na część europejską przypadało 169300 km² i około 6,2 milionów mieszkańców, na obszar Azji Mniejszej (Anatolii) $301400 \mathrm{~km}^{2}$ i ponad 9 milionów ludności, na Armenię i Kurdystan 186500 km², na Syrię, Palestynę i Mezopotamię $637800 \mathrm{~km}^{2}$ i 4,3 miliona, a na obszary na terenie Arabii (Hidżaz, Asir, Al- Hasa i Jemen) 411100 km², zamieszkane przez 1 milion lu$\mathrm{dzi}^{79}$. Była to bardzo skomplikowana mozaika polityczno- etniczna, językowa i pod względem wyznaniowym. Jednak, mimo reform podjętych w XIX wieku, jak też rewolucji młodotureckiej z lat 1908-1909, państwo osmańskie stanowiło relikt przeszłości, daleki od europejskich standardów ${ }^{80}$.

Przed wybuchem wojen bałkańskich naczelnymi organami osmańskich sił zbrojnych były: Ministerstwo Wojny (tur. Harbiye Nezaret, znane też jako Seraskerat), Najwyższa Rada Wojskowa (tur. Şurayi Askeri) oraz Sztab Generalny (tur. Erkan Harbiye Unumiye) ${ }^{81}$. Kompleksowa reforma armii z 1910 roku, podjęta z inicjatywy bardzo wpływowego generała Colmara von der Goltza (znanego tam jako Goltz pasza), głównego doradcy w sprawach sił zbrojnych, zmieniła dotychczasową strukturę dowodzenia i rozmieszczenia poszczególnych okręgów wojskowych i sił tam stacjonujących ${ }^{82}$. Utworzono cztery inspektoraty armii (tur. nizamiye), z których dwa znalazły się w prowincjach europejskich. I Inspektorat, z siedzibą dowództwa w Stambule kierował jednostkami przeznaczonymi do wojny z Bułgarią. Natomiast II Inspektorat

76 Por. A. Krzak, op. cit., s. 60.

77 Por. P.S. Jovett, op. cit., s. 36.

78 Ibidem.

79 Por. T. Rawski, op. cit., s. 78.

80 Por. M. Kukiel, Dzieje polityczne Europy od rewolucji francuskiej, London 1992, s. 438; T. Rawski, op. cit., s. 78 .

${ }^{81}$ W okresie od 29 lipca 1912 do 23 stycznia 1913 roku funkcję ministra wojny i zarazem seraskera (głównodowodzącego) sprawował Nazim pasza, absolwent francuskiej akademii wojskowej St. Cyr, natomiast Szefem Sztabu Generalnego był Ahmed Izzet pasza, który skończył akademię wojskową w Niemczech, późniejszy minister wojny od lipca 1913 do listopada 1913 roku. Por. E. J. Erickson, op. cit., .s 22 i n.

82 Ibidem, s. 17 (tamże wcześniejsza struktura armii i rozmieszczenie jednostek w 1908 roku). 
w Salonikach był odpowiedzialny za zachodni teatr wojenny, tj. działania przeciw Serbii i Grecji ${ }^{83}$. Przebudowę armii oparto na doświadczeniach z niedawnej wojny rosyjsko- japońskiej (1904-1905) i na modelu niemieckim, oprócz tego, sprawdzianem jej sprawności bojowej były podjęte we wrześniu 1910 roku wielkie manewry koło trackiego Lüleburgaz ${ }^{84}$.

Armia osmańska (tur. Osman Ordusu) ${ }^{85}$, liczyła w czasie pokoju około 280 tysięcy żołnierzy. W razie potrzeby, potencjalne możliwości mobilizacyjne teoretycznie mogły powiększyć stan armii tureckiej aż do 700 tysięcy ${ }^{86}$, to jednak wymagało czasu i w sytuacji konfliktu zbrojnego okazywało się trudne do zrealizowania w pełnym zakresie. Główny człon armii sułtańskiej, tj. regularne wojska liniowe, stanowił tzw. nizam, natomiast drugi element to armia rezerwowa i uzupełnienie dla armii liniowej, tzw. ihtiyad. Rekruci odbywali zasadniczą służbę wojskową w ciągu 3 lat, natomiast dalsze $6 \mathrm{w}$ szeregach rezerwy. Następnie mogli służyć w szeregach lokalnych sił rezerwowych lub zapasowych (redif) na przestrzeni kolejnych 9 lat, a potem już jako ochotnicy (müstahfiz). Dawało to łącznie okres 26 lat służby ${ }^{87}$. W wojnach bałkańskich dywizje redif stały się z konieczności istotnym elementem armii osmańskiej ${ }^{88}$.

Największą jednostką na szczeblu taktyczno- operacyjnym była dywizja (tümen). System dywizyjny, na sposób europejski, został wprowadzony w Turcji wraz z reformami C. von der Goltza ${ }^{89}$. Pełnoetatowa dywizja powinna składać się z trzech pułków liczących po około 2,5 tysiąca ludzi, łącznie dawało to około 7,5 tysiąca żołnierzy. Jednak niektórzy twierdzą, że dywizje pierwszej linii liczyły około 12 tysięcy żołnierzy ${ }^{90}$. Poszczególne jednostki miały dość zróżnicowaną wartość bojową. Rdzeń armii stanowili bitni wieśniacy anatolijscy, odporni na trudne warunki bytowania ${ }^{91}$. Pułk (oçak, alay) był złożony z 3 batalionów po 800 ludzi każdy, łącznie 2400 ludzi. Batalion (tabur) tworzyły 4 kompanie. Każda kompania (bölük) składała się z 4 plutonów (bir), każdy po 50 żołnierzy, czyli łącznie 200 żołnierzy 92 . Natomiast drużyna (manga) liczyła 10 żołnierzy ${ }^{93}$. Regulamin organizacji sił zbrojnych przewi-

${ }^{83}$ Ibidem, s. 31 (tam też mapa z podziałem na Inspektoraty); A. Krzak, op. cit., s. 53.

${ }^{84}$ Wzięli w nich udział Zeki pasza, jako dowódca Armii „Wschodniej” przeciw Armii „Zachodniej” Abdullaha paszy. Obaj dobrze byli znani potem z I wojny bałkańskiej, a zwłaszcza Zeki pasza, dowódca Armii Wardarskiej spod Kumanova, por. E. J. Erickson, op. cit., s. 30 (tam również lista jednostek biorących udział w manewrach).

${ }^{85}$ Wcześniej, w 1841 roku nadano oficjalną nazwę osmańskim siłom zbrojnym - Uporządkowani Żołnierze Sułtańscy (Asakir- i Nizamiye-i Şahane). Por. S.J. Shaw, E. K. Shaw, op. cit., s. 149. Wydaje się, że poprawna nazwa winna brzmieć: Żołnierze Sułtańscy Nowego Wzoru lub Nowego Porządku.

${ }^{86}$ Por. P. S. Jovett, op. cit., s. 10- 11.

${ }^{87}$ Ibidem, s. 11.

${ }^{88} \mathrm{O}$ genezie systemu redif $\mathrm{w}$ latach 40 . XIX wieku i reformach wojskowych Mustafy Reşita- paszy, por. szerzej S. J. Shaw, E.K. Shaw, op. cit., s. 150. Na temat redifu w 1908 roku i jego dalszego, dwustopniowego rozwoju, por. E. J. Erickson, op. cit., s. 19 i n.

89 Por. P. S. Jovett, op. cit., s. 24.

${ }^{90}$ Por. R. Rabka, op. cit., s. 76.

${ }^{91}$ Ibidem, s. 76.

92 Por. P.S. Jovett, op. cit., s. 11.

${ }^{93}$ S. J. Shaw, E.K. Shaw, op. cit., s. 150. 
dywał, że każda dywizja piechoty będzie wzmocniona pułkiem artylerii złożonym z 24 dział różnego typu ${ }^{94}$. Dwie, trzy, a niekiedy nawet więcej dywizji tworzyło korpus (tur. kolordu, topluluk). Pełna obsada korpusu liczyła 3 dywizje piechoty, łącznie około 41000 żołnierzy, którym przydzielano 6700 zwierząt jucznych i pociągowych $^{95}$. Poza tym do korpusu dołączano: jeden pułk strzelców, brygadę kawalerii złożoną z trzech pułków, artylerię korpusu (dwie grupy, w każdej po trzy baterie dział), dywizjon haubic, batalion inżynieryjny, grupę do budowy mostów, kompanię telegraficzna, batalion transportowy oraz pododdziały medyczne ze szpitalem ${ }^{96}$. Tureckie siły zbrojne liczyły ogółem 14 korpusów, z czego 7 rozlokowano w Europie ${ }^{97}$. Na obszarze I Inspektoratu stacjonowały Korpusy I, II, III i IV, natomiast na obszarze II Inspektoratu Korpusy V, VI i VII. Na obszarze Albanii, Kosowa i pogranicza z Grecją znalazły się ponadto Dywizje nizam 22, 23 i $24^{98}$.

Wszystkie siły stacjonujące w Macedonii tworzyły Armię Zachodnią lub Armię „Macedonia” (,Makedonya”), na którą składały się w dużej mierze także siły ihtiyad i redifu. Całością dowodził Ali Riza pasza, który miał swą kwaterę główną w Salonikach. Wspomniana Armia Zachodnia była wspomagana przez Armię Wardaru (tur. Vardar Ordusu) będącą de facto jej najsilniejszym członem militarnym, a ponadto przez 3 samodzielne dywizje nizam oraz 11 dywizji z redifu, o mniejszych etatach liczebnych ${ }^{99}$.

Wspomniana Armia Wardaru była dowodzona przez Zeki paszę z Aleppo (tur. Halepli Zeki Paşa, 1862-1943), który został mianowany na to stanowisko niedawno, bo 9 października 1912 roku $^{100}$. Tworzyły ją trzy korpusy. Najliczniejszy (32 tys. żołnierzy) V Korpus, pod dowództwem Kara Said paszy, rozlokowany został wokół miasta Štip (tur. Iştip). VI Korpus, pod dowództwem Dżawid paszy (tur. Cavit Paşa), zajął pozycje wokół Velesu (tur. Kőprülü) i w dolinie Wardaru. Miał liczyć tylko 6 tys. żołnierzy ${ }^{101}$. Wydaje się to mało prawdopodobne, bo było rażącą dysproporcją $\mathrm{w}$ stosunku do reszty sił, nawet uwzględniając system redif, i brak pełnego etatu mobilizacyjnego, musiał on liczyć przynajmniej 10-12 tysięcy ludzi. VII Korpus, dowodzony przez Fethi paszę, i liczący 19 tys. żołnierzy, został rozlokowany wokół miasta Kumanovo. Dodatkowo jeszcze siły Zeki paszy zostały wzmocnione Samodzielną Dywizją Kawalerii ${ }^{102}$. Ta część sił tureckich miała liczyć łącznie 60-66 tysięcy ludzi według różnych danych, a niekiedy nawet miała ona tę liczbę znacznie przekraczać ${ }^{103}$.

\footnotetext{
94 Por. P.S. Jovett, op. cit., s. 11.

95 E. J. Erickson, op. cit., s. 27 (tam też o innych reformach strukturalnych armii osmańskiej).

96 Por. A. Krzak, op. cit., s. 53.

97 Por. J. Rubacha, Butgarski sen, op. cit., .s 250.

98 Por. A. Krzak, op. cit., s. 53.

99 Ibidem, s. 54, przyp. 27.

100 E. J. Erickson, op. cit., s. 169.

101 Por. B. Ratković, M. Đurišić, S. Skoko, op. cit., s. 46- 47.

102 Por. B. Ratković, M. Đurišić, S. Skoko, op. cit., s. 45- 48; E. J. Erickson, op. cit., s. 170- 171.

103 Por. T. Rawski, op. cit., s. 83; E. J. Erickson, op. cit., s. 193. Tadeusz Rawski podaje liczbę 70 tysięcy żołnierzy Armii Wardaru, a Mirosław Dymarski pisze nawet o 100 tysiącach i 190 działach (por.
} 
Trudno powiedzieć, czy poszczególni autorzy wliczają do tego wspomnianą wielkąjednostkę jazdy osmańskiej. Wspomniane korpusy miały różną liczbę dywizji: Korpus $\mathrm{V}$ $-4, \mathrm{VI}-2$ i VII -3.

Typowo osłonowy charakter miały natomiast siły tureckie w Kosowie. Wokół Prištiny umieszczona została Prištinska Dywizja redif oraz 20 DP i 23 DP nizam. Natomiast w Epirze i w Albanii rozmieszczone zostały Dywizja Piechoty „Yanina” redif i Dywizja Piechoty „Berat” redif. Na terenie pogranicza z Grecją od strony północnej Tesalii pozycje zajęly 21 i 24 Dywizje nizam i kilka innych dywizji redif ${ }^{104}$. Plan turecki zakładał przede wszystkim obronę bardzo ważnej strategicznie przełęczy Sarantoporo, broniącej od południa obszaru tureckiej Macedonii. W tym celu wyznaczonych zostało około 30 tysięcy żołnierzy wspomnianych dywizji pod komendą Hassana Taksima paszy. Okazało się jednak wkrótce, że atakująca armia grecka jest trzykrotnie większa, niż się spodziewano (i dość dobrze uzbrojona), i zatrzymanie jej okazało się niemożliwe ${ }^{105}$.

Druga część armii osmańskiej na Bałkanach tworzyła Armię Wschodnią lub Armię „Tracja” (,Trakya”) i była dowodzona przez Abdullaha paszę. W razie potrzeby, jej zadaniem była obrona obszaru Rumelii (Tracji) i podejścia do Adrianopola (tur. Edirne), ale przede wszystkim zagrodzenie siłom inwazyjnym drogi do Stambułu. Ta część armii osmańskiej miała charakter najbardziej istotny. Wojska Armii Wschodniej były podzielone na dwa człony operacyjne. Pierwszy z nich nosił nazwę 1 . Armia Wschodnia - „Południe”, w skład której weszły Korpusy Armii I, II i IV, ponadto jako wsparcie dywizja kawalerii. Natomiast drugi człon tworzyła 2. Armia Wschodnia „Północ”, tj. III, XVII i XVIII Korpusy Armii. Osobnymi jednostkami militarnymi były ponadto Obszar Umocniony Edirne i Garnizon Kyrdżali (tur. Kircaali) ${ }^{106}$. W momencie zakończenia I wojny bałkańskiej (zapewne po poniesionych ogromnych stratach i różnorodnych uzupełnieniach), stan sił tureckich w prowincjach europejskich, jak podaje Philip S. Jovett, miał liczyć 337 tysięcy oficerów i żołnierzy ${ }^{107}$.

Dyslokacja sił tureckich i ich liczebność, wyraźnie wskazywały, że ewentualny front w Sandżaku, czy w interesującej nas Macedonii Wardarskiej miał dla naczelnego dowództwa armii osmańskiej i samego generała Colmara von der Goltza raczej znaczenie pomocnicze, o mniejszej wadze. Priorytetem strategicznym był dla Turków obszar Tracji, z uwagi na wspomnianą siłę militarną i potencjał armii bułgarskiej, a także bliskość Stambułu ${ }^{108}$. Przewidywano rozlokowanie tu aż 293000 wojska liniowego, natomiast w siłach rezerwowych 115 000. We wspomnianej Macedonii Wardarskiej

Konflikty na Bałkanach, op. cit., s. 249). Być może wliczono w tym przypadku także do sił Zeki paszy nieregularne jednostki albańskie w liczbie około 40 tysięcy bojowników.

104 Por. A. Krzak, op. cit., s. 54.

105 Por. R. Rabka, op. cit., s. 74- 75.

106 Por. E. J. Erickson, op. cit., s. 79 (tamże spis dywizji i pułków tureckich tworzących załogę).

107 Por. P.S. Jovett, op. cit., s. 11.

$108 \mathrm{O}$ armii bułgarskiej, jej potencjale bojowym, uzbrojeniu i strukturze, por. m.in. A. Giza, Armia butgarska w latach 1875- 1913, „Studia i Materiały do Dziejów Wojskowości”, t. 32, 1989; R. C. Hall, op. cit., .s. 25; T. Rawski, op. cit., s. 82- 83; J. Rubacha, op. cit., s. 246- 250; R. Rabka, op. cit., s. 52- 60 i 89- 91; M. Dymarski, op. cit., s. 242; A. Krzak, op. cit., s. 56- 59. 
stacjonowało w poszczególnych garnizonach 175-200 tysięcy żołnierzy osmańskich, podczas gdy wojska sojuszu bałkańskiego miały łącznie wystawić 397000 ludzi ${ }^{109}$. Niektórzy historycy podają, że siły tureckie w Europie miały planowo osiagnąć pułap 470000 ludzi i 1050 dział ${ }^{110}$. O ile Turcy mniej obawiali się Serbów i Greków, o tyle sama Macedonia miała dla nich istotne znaczenie strategiczne i komunikacyjne ${ }^{111}$.

Podawane dane różnią się w sposób znaczący, bo według innych autorów owe sprzymierzone armie na szczeblu operacyjnym miały liczyć aż 723 tysiące żołnierzy (Czarnogóra 35 tys., Bułgaria 294 tys., Grecja 108 tys. i Serbia 286 tys.). Natomiast armia osmańska z przewidzianych planem mobilizacyjnym 600 tysięcy wojska mogła wystawić w polu, realnie jedynie 307 tysięcy ${ }^{112}$. Jednak, jak wskazał Robert Rabka, wojska tureckie liczyły (raczej chyba na papierze) znacznie więcej, tj. ponad 340 tysięcy żołnierzy piechoty, w tym 22 dywizje piechoty pierwszej linii - nizam i 6 tysięcy kawalerii Po reformie z 1910 roku każda z nich liczyła sobie 9-11 batalionów piechoty, 1 batalion strzelców, 1 batalion artylerii i oddział kawalerii, ponadto armia sułtańska posiadała około 850-900 dział podzielonych między poszczególne dywizje i inne związki taktyczno-operacyjne ${ }^{113}$.

Naczelne dowództwo liczyło także na istotne wsparcie około 40 tysięcy albańskich plemiennych sił nieregularnych, znanych z bitności i bezwzględności, które miałyby stanąć do walki z Serbami i Czarnogórcami w Sandżaku Novopazarskim oraz z Grekami na terenie południowej Albanii, północnego Epiru (alb. Czamuria) i Macedonii. Potencjalnie Albańczycy (zwani też Arnautami), jako wojska ochotnicze (tur. gönüllü müstahfiz), stanowili bardzo znaczącą siłę zbrojną, z którą dowództwo osmańskie poważnie się liczyło, bo np. tylko lider albański z Kosowa, Isa Bojentin miał otrzymać od Turków aż 60 tysięcy karabinów i strzelb na dozbrojenie i wyposażenie ${ }^{114}$. W sytuacji, gdy brakowało aż kilkaset tysięcy nowoczesnych karabinów dla samych Turków (dodatkowo z podziałem na typy dla kawalerii i piechoty), była to pomoc znacząca.

W razie potrzeby w dalszym rozwoju sytuacji na froncie, plan tureckiego Sztabu Generalnego zakładał wzmocnienie sił i garnizonów bałkańskich armii osmańskiej posiłkami z Bliskiego Wschodu, tj. zwłaszcza z Syrii i Palestyny. Tu jednak potencjalną przeszkodą $\mathrm{w}$ transporcie i szybkim przewozie mas wojska i sprzętu mogła być marynarka wojenna Grecji operująca z baz na Morzu Egejskim ${ }^{115}$. Dla niektórych ofi-

109 Por. R. Rabka, op. cit., s. 73; P.S. Jovett, op. cit., s. 11.

110 Por. A. Krzak, op. cit., s. 54.

111 O znaczeniu Macedonii, podstawach historycznych roszczeń greckich, bułgarskich i serbskich, strukturze etnicznej i wyznaniowej, itp., por. ostatnio S. J. Shaw, E. K. Shaw, op. cit., s. 326- 327. Liczba ludności miała wynosić 3, 2 miliona, z czego ponad 50\% stanowili muzułmanie. Jednak dokładne dane były zależne od tego, kto je sporządzał i kim był z pochodzenia. O skomplikowanej strukturze etnicznej i wyznaniowej tego terytorium na początku XX wieku, danych według Atanasa Szopowa, por. m.in. wcześniej A. Giza, K. Filipow, op. cit., s. 21 i n.

112 Por. T. Rawski, Wojny batkańskie, op. cit., s. 82.

113 Por. R. Rabka, op. cit., s. 72- 73.

114 Ibidem, s. 74.

$115 \mathrm{O}$ działaniach morskich I i II wojen bałkańskich, potencjale marynarki wojennej Turcji i innych państw konfliktu (Grecji i Bułgarii), por. szerzej J. Gozdawa- Gołębiowski, Od wojny krymskiej do bat- 
cerów i żołnierzy osmańskich obrazem wartości armii greckiej było doświadczenie bojowe zdobyte w wojnie turecko- greckiej z 1897 roku, która zakończyła się de facto ogromnym blamażem Grecji i jej armii. Rezultatem tego było lekceważenie Greków przez Turków i brak wiary w ich zdolności bojowe ${ }^{116}$. Podobny stosunek mieli Turcy i do innych przeciwników bałkańskich, tj. Czarnogórców i Serbów.

Widocznym atutem armii osmańskiej było coraz lepsze wyszkolenie oficerów, a nawet żołnierzy niższych stopniem, na co wpłynęło zaangażowanie w celach szkoleniowych oficerów niemieckich i wyjazdy Turków w ramach wymiany, napływające uzbrojenie i ogólny stan morale ${ }^{117}$. Dotyczyło to jednak przede wszystkim jednostek pierwszej linii, bo znacznie gorszy poziom prezentowały jednostki rezerwowe, nie zawsze też wyposażone w nowoczesną broń strzelecką i inną w odpowiedniej liczbie. Reformowana przez oficerów niemieckich armia osmańska miała osiagnąć pełną gotowość bojową dopiero w 1915 roku i wtedy stać się naprawdę groźnym przeciwnikiem nie tylko dla armii bałkańskich. Jednak w momencie wybuchu I wojny bałkańskiej Imperium Osmańskie nie było do niej dobrze przygotowane, ani pod względem liczby żołnierzy, ani wyszkolenia, ani uzbrojenia ${ }^{118}$.

Czynnikiem, który dodatkowo w istotny sposób zaważył na przebiegu początku I wojny bałkańskiej był fakt demobilizacji znacznej części armii i brak pełnych stanów liczebnych w poszczególnych tureckich jednostkach europejskich oraz odpowiedniej ilości uzbrojenia. Także liczne zmiany i przetasowania personalne w latach 1908-1909 i w latach następnych na najwyższych szczeblach władz wojskowych odegrały negatywną rolę.

\subsubsection{Uzbrojenie strzeleckie}

Najbardziej rozpowszechnionym typem rewolweru wśród oficerów armii osmańskiej był półautomatyczny niemiecki Mauser C06 i brytyjsko-belgijski FN Browning M1903. Inne rewolwery przez nich używane to Browning 1900 i austro-wegierski Mannlicher $1903^{119}$. W 1912 roku armia turecka posiadała na stanie jedynie 713 ty-

kańskiej, Gdańsk 1985, s. 442 i n. Na temat floty tureckiej i greckiej, por. także M. Dymarski, op. cit., s. 241- 243; A. Krzak, op. cit., s. 55, 67

116 Por. T. Rawski, op. cit., s. 80.

${ }^{117} \mathrm{Z}$ uwagi na sprzeciw rządu i banków francuskich, co do dalszego udzielania kredytów stale zadłużonej i pogrążonej w kryzysie Turcji na modernizację jej armii, od 1883 roku w tę lukę weszli Niemcy. $\mathrm{Na}$ temat niemieckich inwestycji, dostarczania uzbrojenia Turkom, działalności niemieckiej misji wojskowej i samego generała von der Goltza, genezy budowy kolei Berlin- Bagdad i stosunków niemieckotureckich, por. szerzej m.in. J. Pajewski, op. cit., s. 204 i n.; E. J. Erickson, op. cit., s. 13 i n.; P. Szlanta, Kolej Bagdadzka- polityka mocarstw na Środkowym Wschodzie przed 1914 rokiem, [w:] Konflikty kolonialne i postkolonialne w Afryce i Azji 1869-2006, red. P. Ostaszewski, Warszawa 2006, s. 355, 381- 382; M. Dymarski, op. cit., s. 239- 241; A. Krzak, op. cit., s. 54- 55; S. J. Shaw, E. K. Shaw, op. cit., s. 355, 381- 382 i ostatnio zwłaszcza S. McMeekin, Ekspres Berlin-Bagdad. Kajzer, islam i imperium osmańskie (1898-1918), Kraków 2012.

118 Por. A. Krzak, op. cit., s. 52.

119 Na temat powyższych typów broni krótkiej- Browninga 1900 i Mannlichera 1901 i późniejszych wersji, por. Major F. Myatt, op. cit., s. 174- 175; Ch. Mc Nab, op. cit., s. 14, 19. 
sięcy 404 sztuki karabinów różnego typu, natomiast w razie spodziewanego rozwoju mobilizacji, potrzeby wynosiły blisko 1,1 miliona sztuk broni ${ }^{120}$. Spora część żołnierzy służących w jednostkach bałkańskich Imperium była pozbawiona karabinów, mniej więcej było to około $20 \%{ }^{121}$.

W armii osmańskiej używano kilku podstawowych typów karabinów. Były to dość nowoczesne wówczas Mauser M1890, M1903 i M1905 ${ }^{122}$. Spora partia broni strzeleckiej używanej przez wojsko to coraz bardziej starzejące się pod względem technicznym brytyjskie M1874 Peabody- Martin i jeszcze starsze karabiny Snider i Snider-Enfield ${ }^{123}$. Kawaleria turecka często była zmuszona, z racji braku odpowiednio krótkiego karabinka, używać długich karabinów piechoty, podobnie jednak jak u żołnierzy tego rodzaju broni, także i tu dawało się odczuć coraz bardziej widoczne braki w zaopatrzeniu w odpowiednią ilość broni strzeleckiej ${ }^{124}$.

Istnieją dość widoczne rozbieżności w podawanych liczbach posiadanych przez armię osmańską karabinów maszynowych. Turcy wcześniej używali pewnej liczby francuskiego typu karabinu maszynowego Hotchkiss (znanego też jako St. Etienne), jednak stale pogłębiana współpraca z Niemcami przyniosła import coraz większej ilości Maximów M1909. Na wyposażeniu armii znalazło się od 388 do 556 karabinów maszynowych różnych typów ${ }^{125}$. Niektórzy autorzy podają też liczbę nawet 420 posiadanych sztuk tego rodzaju broni strzeleckiej ${ }^{126}$. Kilkaset posiadanych km-ów rozdzielono między utworzone drużyny strzeleckie. Armia Wschodnia w Tracji posiadała 23 takie drużyny, każda z nich miała po 4 karabiny maszynowe (łącznie dawało to 92 sztuki). Natomiast Armia Zachodnia, w Albanii, Epirze i w Macedonii, wliczając w to także Armię Wardaru podobnych pododdziałów miała $19^{127}$.

\subsubsection{Uzbrojenie artyleryjskie}

Schyłek XIX i pierwsze lata XX wieku przyniosły potrzebę unowocześnienia i zwiększenia posiadanego parku artyleryjskiego armii państw bałkańskich, i armii tureckiej. Ogólna liczba dział osmańskich oscylowała w granicach 770- 900 sztuk różnych typów i kalibru. Na przełomie XIX i XX wieku artyleria turecka zaczęła ulegać przezbrojeniu, a starsze typy dział zaczęto zastępować najnowszym pod względem technicznym sprzętem zakupionym w Niemczech.

\footnotetext{
${ }^{120}$ Por. R. Rabka, op. cit., s. 78- 79; P. Jovett, op. cit., s. 23; A. Krzak, op. cit., s. 55.

${ }^{121}$ Por. I. Despot, op. cit., s. 57.

122 Ibidem, s. 58.

${ }^{123} \mathrm{Na}$ temat tego typu broni, por. Major F. Myatt, op. cit., s. 78 i n.

124 Teoretycznie, na żołnierza miało przypadać 1000 sztuk amunicji, podczas, gdy w przededniu I wojny bałkańskiej miał jej tylko około 600 sztuk, a nawet jak podają niektórzy autorzy tylko 150 . Por. R. Rabka, op. cit., s. 79; A. Krzak, op. cit., s. 55; O tym problemie por. ostatnio także I. Despot, op. cit.,

125 Por. P.S. Jovett, op. cit., s. 33.

${ }^{126}$ Por. B. Ratković, M. Đurišić, S. Skoko, op. cit., s. 38; A. Krzak, op. cit., s. 55.

${ }^{127}$ Por. P. S. Jovett, op. cit., s. 33- 34.
} s. 57. 
Stopniowo przeważającym liczebnie typem używanym w armii osmańskiej stała się nowoczesna armata Krupp M1904s kalibru 75 mm (648 sztuk) i M1910s (88 sztuk). Armia turecka (podobnie jak i bułgarska) zakupiła także armaty polowe Kruppa M96nA kalibru $77 \mathrm{~mm}^{128}$. Odczuwalnym problemem było natomiast zaopatrzenie w działa o ciężkim kalibrze, zwłaszcza klasycznie fortecznym. Do zadań o charakterze typowo oblężniczym była przeznaczona armata Kruppa $105 \mathrm{~mm}$ w liczbie 18 sztuk i taka sama liczba ciężkich haubic kalibru $155 \mathrm{~mm}^{129}$. Sytuacja miała się nieco poprawić, gdy Niemcy rozpoczęli eksport do Turcji armat Kruppa M1905 kalibru $120 \mathrm{~mm}^{130}$. Z takim też stanem artylerii armia turecka rozpoczynała 1912 rok i całkiem nieodległą już wojnę.

\subsection{3. Środki transportu i lotnictwo}

Armia osmańska borykała się z problemem logistyki i transportu, podobnie jak armie jej bałkańskich przeciwników. Podstawowym środkiem transportu, oprócz połączeń kolejowych były konie i inne zwierzęta pociągowe, a zwłaszcza woły, a na górskich bezdrożach także muły. W okresie poprzedzającym konflikt bałkański Turcy mieli na potrzeby wojny 48 tysięcy koni, także mułów i wołów ${ }^{131}$. Jak wcześniej wspomniano, pojazdy mechaniczne napędzane paliwem dopiero się niedawno pojawiły, stąd też ich stosunkowo niewielka liczba. Z liczby 300, jakie ogółem znajdowały się w całym kraju, bliżej nieustalona liczba została oddana na potrzeby armii, głównie na potrzeby dowództwa i niektórych oficerów sztabowych ${ }^{132}$.

Również siły lotnicze, podobnie jak i gdzie indziej na świecie, były dopiero w zalążku. W 1909 roku pierwsi piloci rozpoczęli szkolenie we Francji. Jednak z powodów finansowych proces szkoleniowy został przerwany. W 1912 roku do kraju powróciło kilku lotników, byli to rotmistrz Fesa Bej i kapitan Kenan Jusuf Bej. Lotników w całych siłach zbrojnych było wówczas tylko 10-15, głównie Turków i Francuzów oraz dwóch Niemców ${ }^{133}$. W tym czasie przybyli do Turcji pierwsi piloci niemieccy, którzy mieli zająć się szkoleniem swych tureckich odpowiedników. U progu I wojny bałkańskiej Turcy zakupili łącznie 15 samolotów różnych typów - Deperdussin, Bleriot $\mathrm{XIb}, \mathrm{XI}-2^{134}$. Wchodząc w II wojnę bałkańską w 1913 roku poziom wyszkolenia lotników tureckich był już w sposób widoczny lepszy. By uniknąć własnego ostrzału (zwanego w późniejszych czasach popularnie „friendly fire”), samoloty wojskowe Turcji zaczęto oznaczać symbolami półksiężyca i gwiazdy na czerwonym tle $e^{135}$.

\footnotetext{
128 Por. I. Hogg, op. cit., s. 31.

129 Por. P. Jovett, op. cit., s. 34.

130 Por. I. Hogg, op. cit., s. 44.

131 Por. P.S. Jovett, op. cit., s. 35.

132 Ibidem, s. 35.

133 P.S. Jovett, op. cit, s. 36; A. Krzak, op. cit., s. 56.

134 Por. A. Krzak, op. cit., s. 56.

135 P.S. Jovett, op. cit., s. 36.
} 


\section{PLANY STRATEGICZNE TURCJI I SERBII}

\subsection{PLANY WOJENNE IMPERIUM OSMAŃSKIEGO}

Prowadząc w latach 1911-1912 wojnę z Włochami w Cyrenajce i Trypolitanii, Turcy musieli zdać sobie sprawę ze swego nieprzygotowania do znacznie większej konfrontacji zbrojnej z państwami sojuszu bałkańskiego. Przegrana w Afryce Północnej pokazała fatalny sposób dowodzenia, złą organizację logistyki i łączności, a zwłaszcza niemożność wsparcia militarnego i materiałowego tamtejszych dość słabych liczebnie garnizonów osmańskich przez siły tureckie z Bliskiego Wschodu, o czym zadecydowała także ,wielka polityka"136. Co więcej, armia turecka znajdowała się w momencie dość trudnym - w fazie reorganizacji wewnętrznej. To zjawisko uchwycił trafnie Józef Piłsudski:

„Nieszczęście tureckie chciało jednak, że wojna zastała armię podczas jej reorganizacji, gdy nowe importowane zasady nie zdążyły wnieść do wojska to, co było w nich dobrego, a już potrafiły zniszczyć istotną wartość tego, co było przed reformami. Więcej nawet, reformatorski zapał był tak wielki we wszystkich dziedzinach życia, że wytworzył w umysłach doktrynerstwo idące zwykle w parze z fikcyjnymi, nierealnymi wyobrażeniami o rzeczach i stosunkach. Prawdopodobnie doktrynerstwo zostało wzmocnione jeszcze i przez to, że nauczycielami u Turków byli Niemcy, którzy w każdej dziedzinie mają na eksport doktryny i doktrynki wszelkiego gatunku"137.

Oprócz tego, sytuacja wewnętrzna Imperium Osmańskiego na terenie jej prowincji europejskich nie należała do spokojnych. Teren Albanii i Macedonii stał się obszarem ogarniętym zaburzeniami wewnętrznymi i powstaniami, które były wspomagane z zewnątrz przez Serbię, Bułgarię i Grecję przez działania oddziałów mających charakter typowo dywersyjny. Ponadto ogromnym problemem dla Imperium Osmańskiego stało się trwające od maja 1912 roku powstanie w Albanii, której elity domagały się bardzo szerokiej autonomii politycznej. Powstanie, w którym istotną rolę odgrywali Hasan Prishtina i Bajram Curri ogarnęło obszar Kosowa i środkowej Albanii ${ }^{138}$. Mimo podpisanego porozumienia we wrześniu tego roku, nadającego formalnie ograniczoną autonomię Albańczykom, rządy tureckie w tej części Bałkanów zaczęły się załamywać, a administracja osmańska uległa de facto zupełnemu paraliżowi. Nowy

${ }^{136}$ Z 20 tysięcy ludzi stacjonujących wcześniej, aż około 13 tysięcy żołnierzy przerzucono na teren zbuntowanego wówczas Jemenu. Natomiast znaczną część uzbrojenia wspomnianych jednostek z Trypolitanii i Cyrenajki przewieziono do Stambułu. Podczas wojny Wielka Brytania sprzeciwiła się dostarczeniu posiłków osmańskich przez teren Egiptu. Por. A. Bartnicki, Konflikty kolonialne 1869- 1939, Warszawa 1971, s. 187- 188.

137 Por. J. Piłsudski, Z wojny batkańskiej, [w:] Pisma zbiorowe, Warszawa 1937, t. 3, s. 278; T. Rawski, op. cit., s. 79.

138 Por. m.in. T. Czekalski, Albania w latach 1920- 1924, aparat państwowy i jego funkcjonowanie, Katowice 1998, s. 30; J. Hauziński, T. Czekalski, Historia Albanii, Wrocław 2009, s. 178 i ostatnio S. J. Shaw, E. K. Shaw, op. cit., s. 440- 441. 
rząd turecki Ahmeda Muhtara paszy był zmuszony zawrzeć w obliczu świeżo powstałego, realnego sojuszu bałkańskiego porozumienie z Albańczykami ${ }^{139}$.

Co więcej, część sił tureckich uległa demobilizacji, stąd też potrzeba było stosunkowo szybko, w nagłym trybie, przywrócić armii gotowość do działań operacyjnych. Dnia 29 września 1912 roku została ogłoszona powszechna mobilizacja, w ostatnim momencie, bo siły sojuszu bałkańskiego były już niemal w całkowitej gotowości do podjęcia działań bojowych. Turcja przystapiła zatem do wojny nie w pełni przygotowana, mając nadzieję na uzupełnienie reszty swej armii przez oddziały z Bliskiego Wschodu już w trakcie prowadzonej kampanii.

Osobą w ogromnym stopniu odpowiedzialną za powstanie głównego planu działań był, pozostający w służbie tureckiej i odpowiedzialny za proces szkolenia armii osmańskiej, wspomniany już generał Colmar von der Goltz. Według niego głównym przeciwnikiem zagrażającym Turcji była Bułgaria, między innymi z uwagi na swe położenie geopolityczne, stosunkowo niedużą odległość od Stambułu oraz bardzo znaczący potencjał militarny ${ }^{140}$. Główne siły osmańskie zostały zatem skoncentrowane na obszarze Tracji tak, by w razie potrzeby dokonać ofensywy przeciwko armii bułgarskiej i ją rozbić. Natomiast potencjalne działania przeciwko Serbii i Czarnogórze miały już mniejszą wagę pod względem operacyjnym ${ }^{141}$.

Sztab turecki i jego plan kampanii nie zakładał natomiast zagrożenia ze strony Grecji, bo jego zdaniem Grecy nie byli dostatecznie gotowi do wojny, a przede wszystkim po przegranej greckiej z roku 1897, armia tego państwa, według ocen i szacunków osmańskich, miała nie przedstawiać większej wartości bojowej. Tak, więc nad granicą z Grecją znalazły się tylko stosunkowo niewielkie siły osłonowe. Natomiast na obszarze północnej i północno-wschodniej Macedonii Wardarskiej skupiona została 60-66 tysięczna (w zależności od danych), wspomniana wyżej Armia Wardaru.

\subsection{PLANY I CELE WOJENNE SERBII}

Nastroje w Serbii w związku z oczekiwaniem na nową wojnę przeciwko Imperium Osmańskiemu były bardzo radykalne i generalnie wierzono w zwycięstwo, tym bardziej, że wojna włosko-turecka z lat 1911-1912 wyraźnie ukazała słabość polityczną i militarną Turcji. Oprócz tego, w Belgradzie panowało przekonanie, że niedawno powstała koalicja sojuszu bałkańskiego, dysponująca bardzo znaczącym potencjałem militarnym, będzie bardzo skuteczna w działaniu. Media i ówczesna propaganda, bazująca zresztą na tradycji walk z Turkami i nadziei definitywnego wyparcia Osmanów z Europy, dzięki zespolonemu wysiłkowi państw bałkańskich, umiejętnie potrafiły rozbudzić w Serbii nastroje konfrontacji i spodziewaną perspektywę rychłego powiększenia granic państwa. Na dzień początku mobilizacji wyznaczony został

\footnotetext{
139 J. Hauziński, T. Czekalski, op. cit. s. 178.

140 Por. A. Krzak, op. cit., s. 70- 71.

${ }^{141}$ Ibidem, s. 71.
} 
30 września. Tylko w samym Belgradzie podczas jej trwania zaciągnęło się lub zgłosiło dobrowolnie aż 1/3 (męskiej) ludności stolicy ${ }^{142}$.

Dla Królestwa Serbii priorytetem było opanowanie jak największego obszaru Macedonii Wardarskiej (na tyle ile to będzie możliwe przy rywalizacji z Bułgaria). Stąd też nad jej północną granicą skoncentrowane zostały wspomniane siły 1 i 2 Armii. Natomiast 3 Armia miała osłaniać od zachodniej, tj. kosowskiej strony prawe skrzydło sił głównych Miała także do pokonania najdłuższą drogę na pozycje wyjściowe ${ }^{143}$.

Plany Sztabu Głównego zakładały atak na główne siły tureckie zgromadzone w trójkącie terytorialnym Üsküb/Skopje- Iștip /Štip- Köprülü/Veles i ich zniszczenie $^{144}$. Przewidywano szybką mobilizację $w$ ciagu tygodnia wszystkich wielkich jednostek $\mathrm{i}$ ich skoncentrowanie na obszarach nadgranicznych z Imperium Osmańskim ${ }^{145}$. Pierwszym z głównych celów było opanowanie Skopje - głównego ośrodka administracyjnego wilajetu i siedziby tamtejszego walego, a następnie Velesu, Štipu i Monastiru (tur. Manastir, obecnie Bitola), Tetova i Ochrydu. To zadanie miały wykonać Armie 1 i 3, zgrupowane w rejonie miasta Vranje. Natomiast siły 2 Armii, wsparte przez bułgarską 7 Dywizję Rilską dowodzoną przez generała Georgi Todorowa miały przejść z rejonu Kjustendiłu i Dupnicy, a potem uderzyć najpierw na garnizon turecki pogranicznej Krivej Palanki (tur. Egri Palanga) ${ }^{146}$. Następnie po jej opanowaniu skierować się w kierunku Ovčego Polja, na południe od Skopje i zamknąć okrążenie (rzekomo) zgromadzonych tam sił tureckich. Dodatkowym zadaniem 2 Armii było zapobieżenie ewentualnemu nadejściu posiłków osmańskich z terenu Tracji ${ }^{147}$.

Na tym terenie głównym przeciwnikiem Serbów stała się Armia Wardaru dowodzona przez Zeki paszę ${ }^{148}$. Serbowie zakładali błędnie, że główne siły osmańskie rozlokują się na Ovčim Polju i tam też wszystkie trzy wspomniane wyżej armie serbskie miały się spotkać, a następnie podjąć decydujące działania bojowe, by zniszczyć tam wojska Zekiego paszy ${ }^{149}$.

Natomiast do typowo pomocniczej operacji na terenie Sandżaku Novopazarskiego i zajęcia Novego Pazaru (tur. Yeni Bazar) oraz Kosovskiej Mitrovicy (alb. Mitrovicë) wyznaczone zostały siły Armii Ibarskiej. Skoncentrowana ona została w rejonie Raški, jako osłona prawego skrzydła głównych sił serbskich 1 i 3 Armii. Odwód stra-

142 Por. M. Dymarski, op. cit., s. 34.

143 Por. T. Rawski, op. cit., s. 83.

144 Por. R. Rabka, op. cit., s. 64.

$145 \mathrm{Na}$ temat planów wojennych i mobilizacji serbskiej, por. ostatnio I. Despot, op. cit., s. 68- 73.

146 Por. R. Rabka, op. cit., s. 64.

147 Ibidem, s. 64.

148 Generał Ž. Mišić szacował liczebność Armii Wardarskiej na 104 000, natomiast Dżawid pasza zaledwie na 50000 żołnierzy. Tak niska liczebność, przedstawiana przez Dżawid paszę, była spowodowana, jego zdaniem, zbyt późną mobilizacją. Z tego powodu armia ta nie osiagnęła pełnej gotowości bojowej, która miała wynieść 123 tysiące. Por. także T. Rawski, op. cit., s. 83; R. Rabka, op. cit., s. 73.I. Despot, op. cit., s. 61.

149 Por. B. Ratković, M. Đurišić, S. Skoko, op. cit., s. 76. 
tegiczny stanowiła Brygada „Javor”, która w razie potrzeby miała wspomóc Armię Ibarską w Sandżaku ${ }^{150}$. Pierwotnie miała ona obserwować ruchy armii austro-węgierskiej. Serbowie nie wiedzieli, jakie są zamiary jej dowództwa i obawiali się, że armia ta może powtórnie zająć Sandżak, który pozostawał pod kontrolą Austro-Węgier do 1908 roku $^{151}$. Dalszym rozwinięciem działań Armii Ibarskiej oraz Brygady „Javor” było dotarcie do Adriatyku, realne współdziałanie z armią czarnogórską i wkroczenie na teren północnej i środkowej Albanii ${ }^{152}$. Nadrzędnym celem było uzyskanie na tym terenie przez Serbów dostępu do morza.

Jak widać z powyższego zestawienia, główne zadanie przypadło w udziale 1 Armii, dlatego też była ona najliczniejszą z wielkich jednostek serbskich, a na jej wyposażeniu znalazło się od 148 do 172 dział i aż 100 karabinów maszynowych ${ }^{153}$. Była to aż 1/3 artylerii, jaką posiadała armia serbska, i niemal połowa jej karabinów maszynowych. To wyraźnie wskazywało, jaką wagę przykładało dowództwo naczelne w Belgradzie do tego kierunku uderzenia.

\section{SYTUACJA W OSTATNICH MIESIĄCACH POKOJU I WYBUCH WOJNY}

Zbliżającą się szybko perspektywę wybuchu nowego konfliktu bałkańskiego próbowały powstrzymać mocarstwa mediując między Turcją, a jej przeciwnikami. Dyplomaci zachodni starali się przekonać Osmanów do przeprowadzenia rzeczywistych, a nie pozorowanych reform wewnętrznych w Macedonii, co teoretycznie mogło odsunąć widmo konfrontacji i złagodzić narastające od dawna nastroje antytureckie ${ }^{154}$. Bułgarzy i pozostali sojusznicy znali też od dawna osmański sposób postępowania, „metodę wiecznych obietnic” i unikanie konkretnych działań, stąd też wiedzieli, że do poprawy sytuacji raczej nie dojdzie. Widoczny wzrost napięcia nastąpił 23 września, gdy w Skopje i w Salonikach tureckie służby celne zatrzymały 20 wagonów, które przybyły z Francji ze sprzętem wojskowym dla państw bałkańskich ${ }^{155}$. Decyzja o ogłoszeniu mobilizacji w dniu 29 września oznaczała de facto bardzo bliski wybuch wojny. Planowa realizacja mobilizacji w państwie osmańskim miała trwać 45 dni, jednak nie udało się jej w pełnym wymiarze zrealizować ${ }^{156}$.

Wodpowiedzipaństwa sojuszubałkańskiego takżeogłosiłymobilizację. Odrzucona została propozycja mocarstw w sprawie reform wewnętrznych w Macedonii. Bułgaria,

150 Por. T. Rawski, op. cit., s. 83.

151 Por. R. Rabka, op. cit., s. 63.

152 Ibidem, s. 63.

153 Por. B. Ratković, M. Đurišić, S. Skoko, Srbija i Crna Gora u Balkanskim ratovima 1912- 1913, Beograd 1972, s. 70. Inne dane podaje Richard Hall- według niego siły 1. Armii miały liczyć jedynie 60 tysięcy wojska, natomiast posiadały aż 172 działa (por. tegoż, The Balkan, op. cit., s. 67).

154 Por. A. Giza, K. Filipow, op. cit., s. 54.

155 Ibidem, s. 54.

156 Por. J. Rubacha, op. cit., .s 229; A. Krzak, op. cit., s. 70- 71. 
Serbia i Grecja również wystosowały wobec Turcji notę z żądaniem wewnętrznych zmian w Macedonii, w tym autonomii dla ludności słowiańskiej, jak również przekazania dowództwa nad żandarmerią oraz wyższych urzędów wilajetach z chrześcijańską większością w ręce ludzi z Zachodu - Belgów lub Szwajcarów ${ }^{157}$. Koalicja dawała Turkom termin 6 miesięcy na realizację owych żądań i spodziewanych reform, zapowiadając jednocześnie własną kontrolę ich wykonania, niezależną od kontroli ze strony mocarstw. Państwa bałkańskie potrzebowały pretekstu, by odium odpowiedzialności politycznej za wybuch konfliktu spadło na Osmanów. Żądania koalicjantów były nie do przyjęcia dla Turków, a odrzucenie ich oznaczało wojnę, którą i tak jeden z członków koalicji - Czarnogóra rozpoczęła już 8 października ${ }^{158}$.

18 października 1912 roku Serbowie przekroczyli granicę turecką na terenie Kosowa rozpoczynając działania wojenne. Tego samego dnia Bułgarzy wypowiedzieli wojnę Turcji i jednocześnie rozpoczęli ofensywę w Tracji, a Grecy uderzyli na obszarze Macedonii Egejskiej ${ }^{159}$. Początek wojny stał się faktem.

\section{BITWA POD KUMANOVEM (23-24 PAŹDZIERNIKA 1912 R.)}

Działania wojenne rozpoczęła 3 Armia generała Božidara Jankovicia, która 18 października forsownym marszem skierowała się na pogranicze serbsko-kosowskie, gdzie napotkała silny opór Turków (a właściwie Albańczyków) pod miejscowością Merdare. Do przewidzianej planem strategicznym pozycji wyjściowej doszła ona dopiero 21 października, gdy pozostałe siły serbskie wkroczyły już na teren północnej i północno-wschodniej Macedonii ${ }^{160}$. W dniu 22 października żołnierze 3 Armii weszli na Kosowo i opanowali Prištinę (alb. Prishtina) ${ }^{161}$. Po drodze Serbowie zajęli także wieś Podujevo (alb. Podujevë) bronioną przez pomocnicze siły albańskie ${ }^{162}$. Udało im się przejąć pewną ilość skrzyń z amunicją, znaczne zapasy żywności, a ponadto 8 wołów pociągowych ${ }^{163}$. Inne oddziały 3 Armii generała Jankovicia znalazły się w rejonie Novego Pazaru, Raški i miejscowości Nova Varoš, witane gorąco przez zamieszkałą tam ludność serbską i czarnogórską ${ }^{164}$, znacznie chłodniej przez ludność albańską, zwłaszcza że oprócz Prištiny został zajęty Prizren, co symbolicznie interpretowano, jako przywrócenie Kosowa po wiekach Serbii ${ }^{165}$.

157 O problemie reform w Macedonii, por. I. Stawowy- Kawka, op. cit., s. 154 i n.; A. Giza, K. Filipow, op. cit., s. 54.

158 Por. A. Giza, K. Filipow, op. cit., s. 54.

159 Por. A. Giza, K. Filipow, op. cit., s. 54; S. J. Shaw, E. K. Shaw, op. cit., s. 450- 451.

160 Por. T. Rawski, op. cit., s. 85.

161 Por. B. Ratković, M. Đurišić, S. Skoko, op. cit., s. 50 i n.

162 Servian successes, „The New York Times”, Oct. 22, 1912, http://query.nytimes.com/mem// archive-free/pdf? res=9900E2DC133CE663A25751C2A9669D94639606CF.

163 Ibidem

164 Ibidem.

165 Por. M. Dymarski, Konflikty, s. 250 


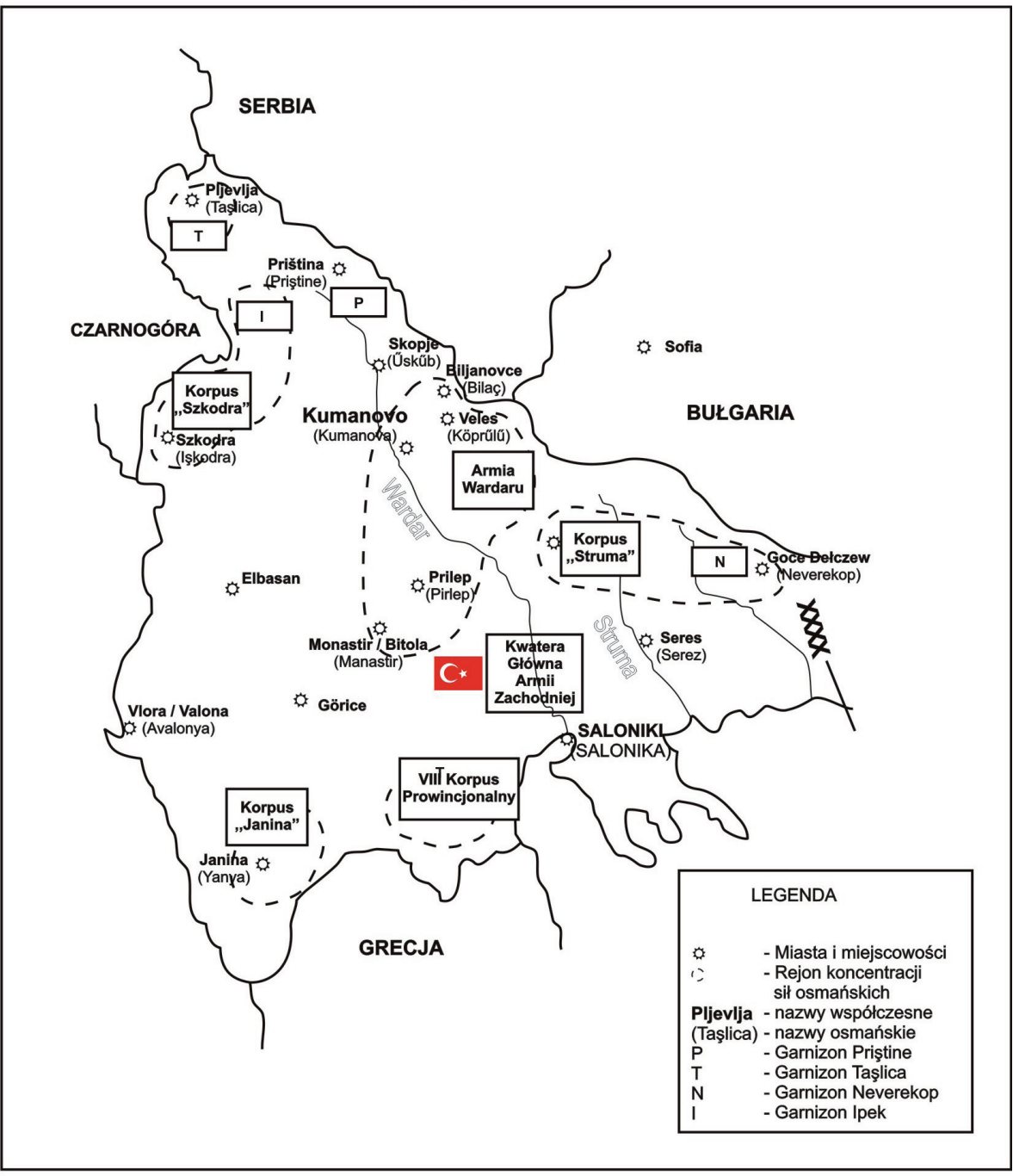

Mapa 1. Obszar koncentracji osmańskiej Armii Zachodniej. Macedoński Teatr Wojenny stan z 19 października $1912 \mathrm{r}$.

Źródło: E. J. Erickson, Defeat in Detail: The Ottoman Army in the Balkans, 1912-1913, London 2003, s. 164

Szybkie postępy ofensywy serbskiej zaniepokoiły Austro-Węgry, które zagroziły interwencją swej armii z obszaru Bośni i Hercegowiny. Zmusiło to dowództwo Serbów do zmiany planów. Armia Ibarska otrzymała rozkaz wycofania się z obszaru Metohiji i przygotowania do obrony Novego Pazaru, a Brygada „Javor” miasteczka Sjenica w zachodniej części Sandżaku ${ }^{166}$.

166 Ibidem, s. 250. 

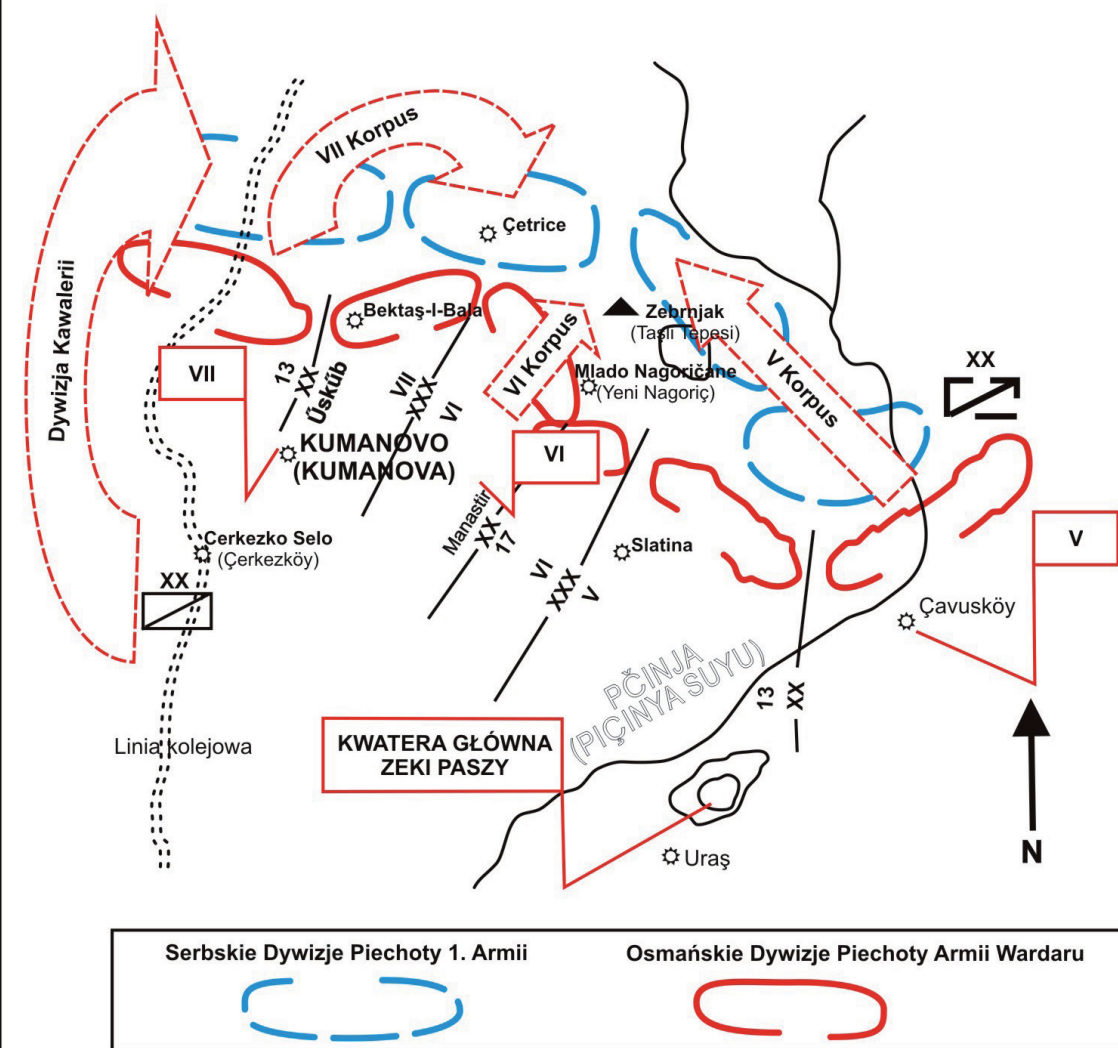

Osmańskie Dywizje Piechoty Armii Wardaru

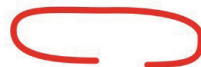

Mapa 2. Plan operacyjny Armii Wardaru z dnia 24 października 1912 roku

Źródło: E. J. Erickson, Defeat in Detail: The Ottoman Army in the Balkans, 1912-1913, London 2003, s. 177.

Natomiast 1 Armia księcia Aleksandra przekroczyła granicę 18-20 października idąc w trzech kolumnach w kierunku Kumanova. Serbowie przygotowali się także pod względem propagandowym do przejmowania ziem macedońskich, wydając 18 października stosowną odezwę. Mówiła ona o „uwolnieniu swych braci spod jarzma tureckiego”, ,przywróceniu pokoju i porządku na naszych rodzinnych ziemiach", nawoływano też do przywitania wkraczających oddziałów, określonych mianem „dzielnych rycerzy”167. Odezwa prosiła też o „poniechanie odwetu na tych, którzy jeszcze wczoraj byli panami [tj. Osmanach], zgodnie z duchem chrześcijańskiego miłosierdzia""168.

167 Por. D. Gibas- Krzak, Wojny bałkańskie 1912- 1913 przyczyna nacjonalizmu „gorqcego” na Batkanach w XX wieku. Zarys problemu, „Balcanica Posnaniensia. Acta et Studia”, t. XIX, 2012, s. 133.

168 Po zakończeniu wojen bałkańskich Macedonia Wardarska i Egejska zostały poddane intensywnej serbizacji i hellenizacji. O polityce Serbii, Bułgarii i Grecji wobec mieszkańców Macedonii, por. A. Giza, 
Maszerując przełęczą między pasmami górskimi Kozjak i Crna Gora, pod wieczór 22 października, siły 1 Armii znalazły się na pozycjach wyjściowych w okolicach Kumanova ${ }^{169}$. Podczas marszu zajęto m.in. wieś Zubovce (tur. Zibefçi) na płd. wsch. od miasta, gdzie książę przeniósł swoją kwaterę główną z Vranja ${ }^{170}$. Z kolei czołowe oddziały 2 Armii generała Stepy Stepanovicia (DP „Timok” I poziva) maszerowały wraz Bułgarami od 18 października z rejonu Kjustendiłu i Dupnicy. Połączone siły szły doliną rzeki Bregalnicy i tego samego dnia wyparły batalion turecki z miejscowości Carevo Selo. Stamtąd, posuwając się z biegiem rzeki w kierunku Krivej Palanki, którą zajęły w walce, weszły w kontakt bojowy z siłami V Korpusu osmańskiego. W walce z nim zdobyły ważną pozycję Sultantepe koło miejscowości Osogovo (tur. Oşigova) i stoczyły walkę koło wsi Biljanovce (tur. Bilaç) $)^{171}$. Tureckiej 19 DP nizam udało się tam powstrzymać DP „Morava” (I) na przeciąg jednego dnia, ale wobec przewagi serbskiej musiała ona dokonać odwrotu pod Kumanovo ${ }^{172}$. Czołowe jednostki 2 Armii doszły 21 października do wsi Stracin (tur. Straçin), którą zajęły w walce i tam nawiązały łączność z częścią wojsk księcia Aleksandra ${ }^{173}$. Pod wieczór, 22 października wszystkie trzy armie serbskie były już rozwinięte dużym półkolem od Prištiny przez okolice Kumanova do okolic Stracina ${ }^{174}$. „The New York Times" w swej relacji z 22 października informował, że wszyscy ranni w dotychczasowych starciach żołnierze serbscy zostali umieszczeni w szpitalu w Nišu i tam odznaczeni przez króla Piotra ${ }^{175}$.

Usytuowanie strategiczne Kumanova było dość widoczne. Leży ono w środkowej części północnej Macedonii niedaleko granicy serbskiej, poza tym miasto to znajduje się 39 km na północny wschód od Skopje ${ }^{176}$. Naczelne dowództwo Serbów spodziewało się obecności głównego zgrupowania osmańskiego Armii Wardaru i co za tym idzie, dużego oporu tureckiego dopiero na Ovčim Polju. Tymczasem Zekiemu paszy udało się przejść ten obszar i jeszcze wieczorem, tego samego 22 października, jego oddziały znalazły się na pozycjach wyjściowych do ataku na część 1 Armii serbskiej, zmierzającej dopiero na pole przewidywanego starcia ${ }^{177}$. Turecki dowódca umieścił swą kwaterę główną we wsi Uraş za rzeką Pčinją (tur. Piçinya -suyu) dopływem Wardaru łączącym się z Krivą Reką na wschód od Kumanova. Armia Wardarska

Państwa bałkańskie, op. cit., s. 144 i n.; I. Stawowy - Kawka, Historia Macedonii, Wrocław 2000, s. 170; D. Gibas- Krzak, op. cit., s. 134- 136.

169 Droga wojsk serbskich, krajobraz naturalny byłego pola bitwy pod Kumanovem i okolic miasta oraz sieć osadnicza są możliwe do zrekonstruowania dzięki współczesnym mapom satelitarnym. Por. m.in. Kumanovo Map- Satellite Images of Kumanovo, http://www.maplandia.com/macedonia/kumanovo/kumanovo/kumanovo.

${ }^{170}$ Por. Servian successes, op. cit.

${ }^{171}$ Ibidem; E. J. Erickson, op. cit., s. 171.

172 Ibidem, s. 171.

173 Por. B. Ratković, M. Đurišić, S. Skoko, op. cit., s. 66- 67.

174 Por. T. Rawski, op. cit., s. 85.

175 Por. Servian successes, op. cit.

176 Por. R. W. Hall, op. cit., s.

177 Por. T. Rawski, op. cit., s. 85. 
skoncentrowała znaczną część swych sił w dolinie tej rzeki. Natomiast dwie dywizje tyłowe 3 Armii tureckiej - 18 DP nizam i DP „Drama” redif nie dotarły pod Kumanovo i wciąż jeszcze znajdowały się pod Monastirem ${ }^{178}$.

O ile Zekiemu paszy udało się zdobyć dość dokładne informacje na temat rozmiarów sił przeciwnika i zajmowanych przez niego pozycji, o tyle Serbowie nie zdawali sobie sprawy, że czeka ich starcie z głównymi siłami tureckimi. Nie spodziewając się ataku, część wojsk 1 Armii, mimo dość sprzyjających warunków terenowych, w żaden sposób nie umocniła swych pozycji ${ }^{179}$. Żołnierze nie dostrzegając zagrożenia nawet się nie okopali, nie mówiąc o innych zabezpieczeniach, np. linii zasieków i zapór oraz sporządzeniu stanowisk dla karabinów maszynowych i dział.

Na pięć serbskich dywizji piechoty 1 Armii tylko dwie z nich zaczęły rozbijać obozowiska i zajmować pozycje bojowe na przyszłym polu bitwy. Lewe skrzydło tworzyła DP „Dunav” (I), a prawe DP „Morava” (I), za nimi natomiast znalazła się Dywizja Kawalerii. Ich lewa flanka była zupełnie odsłonięta, ponieważ wieś Srtevica (tur. Paşatepeleri, dziś nieistniejąca) była zajęta przez rezerwowe siły tureckie DP „„štip” redif ${ }^{180}$. Pod osłoną nocy, z 22 na 23 października, siły VI Korpusu osmańskiego, stanowiące centrum ugrupowania bojowego Armii Wardaru, przekroczyły nurt Pčinji i zajęły pozycje wyjściowe do ataku na ważnym strategicznie wzgórzu Zebrnjak. Natomiast główne siły V Korpusu (15 i 16 DP nizam) pozostały na lewym brzegu rzeki jako siły odwodowe, chroniące drogę od strony Stracina i Kočani (tur. Koçan) tworząc prawy skraj pozycji obronnej od strony 2 Armii serbskiej. Na lewym skrzydle pozostały natomiast główne siły VII Korpusu ${ }^{181}$.

Ranek 23 października był bardzo mglisty utrudniając dokładną obserwację i rozpoznanie ruchów przeciwnika. Serbscy zwiadowcy zauważyli na swej lewej flance przemieszczające się oddziały 17 DP nizam, lecz wzięli ją przez pomyłkę za jakieś tureckie baterie wycofujące się w odwrocie. Siły serbskiego 18 pułku DP „Dunav” (I), które nieostrożnie wysunęły się do przodu i próbowały je zaatakować, zostały odparte silnym ogniem artyleryjskim oraz ogniem z karabinów maszynowych, podobnie jak i zwiad z Dywizji Kawalerii ${ }^{182}$. Obserwując ruchy sił serbskich, Zeki pasza doszedł do wniosku, że lewe skrzydło przeciwnika jest dość słabe ${ }^{183}$.

Nie widząc oznak aktywności oddziałów czołowych 2 Armii rozlokowanych koło Stracina, dowódca osmański zdecydował się na podjęcie ataku. Około godziny 11.00, po intensywnym przygotowaniu artyleryjskim, Turcy rozpoczęli zmasowane natarcie na siły armii księcia Aleksandra ${ }^{184}$. Oddziały VI i VII Korpusu przypuściły atak skierowany ku pozycjom DP „Dunav” (I). Niedługo potem, 13 i 17 Dywizje osmańskie nizam zmusiły 18 pułk piechoty do bezładnego odwrotu. Działa serbskie i turec-

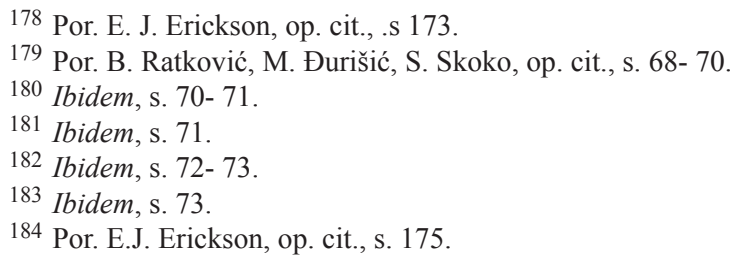


kie cały czas prowadziły wymianę ognia ${ }^{185}$. Dla wzmocnienia i kontynuacji natarcia, Zeki pasza potrzebował jednak przybycia z tyłów DP „Ištip” redif, by jeszcze silniej zaatakować serbskie skrzydło i potem wyjść na jego tyły. To jednak dało Serbom potrzebny czas i umożliwiło 7 pułkowi DP „Dunav” wesprzeć mocno osłabiony 18 pułk i przejść do aktywnej obrony. Dzięki przybyciu na miejsce walk 8 pułku tejże dywizji było możliwe istotne wzmocnienie lewej flanki. Na nie skierowało się od strony Srtevicy silne natarcie DP „Ištip”. Także V Korpus zaangażował całość sił do walki. Z kolei na prawej flance, 9. pułk piechoty utrzymał swe pozycje atakowany przez DP „Manastir” redif. W południe około 45 tysięcy Turków atakowało 30 tysięcy Serbów na froncie długości około $20 \mathrm{~km}^{186}$.

Około godziny 12.00 rozpoczął się także atak oddziałów VII Korpusu Fethi paszy, wspartych przez ogień baterii armat polowych i górskich, na linie zajmowane przez DP „Morava” (I) ${ }^{187}$. Serbowie słysząc od zachodu ogień dział i huk strzałów wiedzieli, że bitwa rozgorzała na dobre. Jednak po początkowych postępach osmańskich w głąb pozycji wroga, siły serbskie twardą obroną zatrzymały natarcie, co więcej, podjęły kontratak i wyparły Turków na pozycje wyjściowe. VII Korpus stracił w tym starciu kilkuset zabitych. Do walki włączyły się także oddziały tureckiej Samodzielnej Dywizji Kawalerii, wspierane ogniem artyleryjskim tegoż Korpusu. Jednak jeźdźcy osmańscy nie wytrzymali ostrzału serbskiego i tracąc pewną część poległych, musieli się wycofać w kierunku wsi Cerkesko Selo (tur. Çerkezkőy) ${ }^{188}$. Po udanym kontrataku Serbów, siły tureckie były trzymane na dystans przez umiejętnie prowadzony silny ogień artyleryjski i karabinów maszynowych, który trwał przez resztę dnia. Natomiast na prawym skrzydle 53 pułk piechoty V Korpusu zaatakował oddziały serbskiej kawalerii i włamał się w serbskie linie. Do ataku ruszyły też 13 DP i DP „Iştip” na północ od ówczesnej wsi Çavuskőy. Jednak po południu natarcie tureckie na tym odcinku zostało zatrzymane. Pod koniec dnia sytuacja wyglądała następująco: V Korpus zatrzymał Serbów na linii Pčinji, VI Korpus nadal kontynuował natarcie na kierunku wsi Mlado Nagoričane (tur. Yeni Nagoriç), a VII Korpus znajdował się w rejonie ówczesnej wsi Bektaşi- I- Bala ${ }^{189}$.

Podkreślić należy, że jednostki rezerwowe pozostające na tyłach frontu, tj. DP „Dunav” (II), DP „Drina” (I) i DP „Timok” (II) i czesść jednostek artylerii armijnej miały bardzo niewielkie pojęcie o aktualnej sytuacji bojowej, nie były też zresztą o niej dostatecznie informowane. Cały czas tkwiły na tyłach i nie wzięły udziału w pierwszym dniu bitwy. Również dowództwo 1 Armii nie posiadało dokładnych informacji o coraz bardziej zaciętych i intensywnych walkach toczonych przez niektóre jej dywizje i nie miało wpływu na sytuację poszczególnych jednostek ${ }^{190}$. Nie mając dostatecznej wiedzy o rozgrywającej się pod Kumanovem bitwie, książę Aleksander

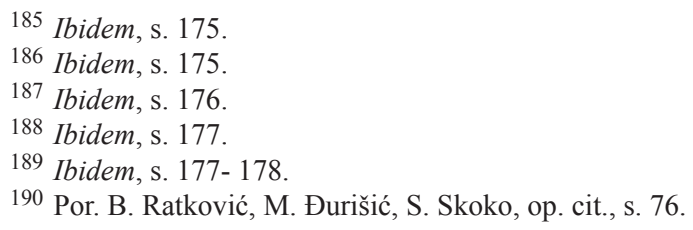


i generałowie ze sztabu 1 Armii, nie zdawali sobie sprawy, że właśnie tam trwa główne natarcie tureckie, a nie na spodziewanym Ovčim Polju ${ }^{191}$.

Pomimo tego faktu i braku łączności dowództwa serbskiego z toczącymi zacięty bój własnymi dywizjami, prowadzone 23 października przez Osmanów natarcie nie odniosło sukcesu i nie przełamało sił serbskich. Przypuszczając, że siły Zekiego paszy znajdują się na południe od Kumanova, na Ovčim Polju, dowództwo 1 Armii wydało rozkaz kontynuowania marszu na południe w stronę Sveti Nikole i Velesu tak, jak zakładano pierwotnie. Dopiero po północy 24 października sztab 1 Armii otrzymał raport z DP „Dunav” I poziva, że ,jest ona atakowana przez bardzo silne oddziały wroga i że poniosła ciężkie straty". Trudno było jednak w tym momencie nagle zmienić wydane rozkazy i całą logistykę marszu aż trzech dywizji. Mimo to, udało się 1 Armii uniknąc totalnej katastrofy, bo wciąż posiadała ona nietknięte odwody, które można było, choć z trudem, zawrócić i skierować pod Kumanovo. Dywizje tyłowe maszerowały całą noc, ale rano poszczególne oddziały zaczęły docierać w końcu na pole bitwy ${ }^{192}$. Z drugiej zaś strony oddziały osmańskie kilkakrotnie jeszcze podejmowały natarcie na pozycje Serbów. Turcy poczynili pewne postępy, spychając pierwszą linię serbską do głębokiej defensywy. Zeki pasza oraz jego oficerowie sztabowi zaczęli wierzyć, że następny dzień przyniesie załamanie pozycji serbskich i zwycięstwo. W nocy z 23 na 24 października, dowództwo tureckiej 18 DP z Monastiru otrzymało rozkaz szybkiego marszu, by wesprzeć siły Zekiego paszy, oprócz tego dochodziło do sporadycznego ognia artyleryjskiego ${ }^{193}$.

24 października o godzinie 5.30 siły serbskie rozpoczęły nowy dzień bitwy ogniem artylerii. Od ich ognia poniosły straty DP „Manastir” i „Üsküb”, mimo to po przegrupowaniu rozpoczęły natarcie ${ }^{194}$. Zmasowane siły VI Korpusu dążyły do związania walką jak największej liczby jednostek serbskich, podczas gdy DP „Ištip” redif przypuściła atak na skrzydło serbskie. DP „Dunav” (I) znalazła się pod ciężkim ogniem i zaczęła nie wytrzymywać natarcia osmańskiego. Jednak o godzinie 10.00 na pole bitwy dotarły oddziały DP „Dunav” (II), które wsparły swą imienniczkę I grupy poborowej, co pozwoliło na wzmocnienie obrony i stopniowe zatrzymanie ataku tureckiego ${ }^{195}$. W tym samym czasie serbska Dywizja Kawalerii przeprawiła się na lewy brzeg Pčinji i powoli zaczęła wypierać Turków z pozycji wokół Srtevicy. Około godziny 12.00 oddziałom DP „Dunav” (II) udało się przełamać obronę i zatrzymać atak tureckiego prawego skrzydła.

Natomiast na lewym skrzydle Armii Wardaru doszło do wydarzenia, które niespodziewanie znacznie pogorszyło ogólną sytuację wojsk tureckich pod Kumanovem. Na wieść o zdobyciu Prištiny przez siły 3 Armii generała Jankovicia i ich spodziewanym marszu na Skopje, upadło morale żołnierzy albańskich z DP „Üsküb” z VII Korpusu, którzy masowo zdezerterowali, opuszczając swe pozycje ${ }^{196}$. Część żołnierzy turec-

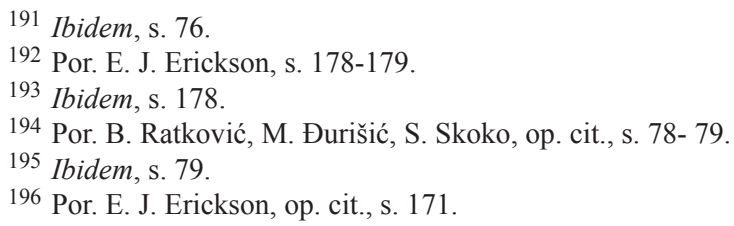


kich, zwłaszcza młodych i niedoświadczonych była także już bardzo zmęczona prowadzonymi walkami, a oprócz tego, niektórym jednostkom mocno skurczyły się zapasy amunicji. Tak było też i we wspomnianej DP „Üsküb”, która swe składy miała $5 \mathrm{~km}$ dalej i trudno jej było na bieżąco uzupełniać braki ${ }^{197}$.

W centrum oddziały tureckie VI i częściowo VII Korpusu uderzyły na pozycje Serbów wczesnym rankiem ${ }^{198}$. Zaatakowano oddziały DP „Morava” (I), jednak mimo początkowych sukcesów atak turecki został w końcu zatrzymany przez silny ogień karabinów maszynowych i opór serbski. Około 7.30 sytuacja zaczęła się stopniowo zmieniać. Wraz z siłami DP „Timok” (II), która dotarła z tyłów, „Morava” rozpoczęła kontratak ${ }^{199}$. Połączone siły serbskie przypuściły teraz zmasowany szturm na lewe skrzydło Osmanów. Serbowie niespodziewanie odnieśli bardzo istotny sukces 7 pułk piechoty z DP „Morava” (I) zdecydowanym atakiem dokonał na swym odcinku wyłomu. To pociagnęło za sobą dalsze ofensywne działania jednostek serbskich. „Moravę” wsparła Dywizja „Timok”, co doprowadziło do dalszego załamania linii Turków i zmuszenia ich do odwrotu. Lewe skrzydło i centrum tureckiego ugrupowania bojowego zaczęło niebezpiecznie się chwiać200.

Ostateczne rozstrzygnięcie nastąpiło jednak w innym miejscu i w późniejszych godzinach. Około 9.30 pod Kumanovo przybyły oddziały DP „Drina” (II) i uderzyły na pozycje V i VI Korpusu ${ }^{201}$. Kolejne ogniwo obrony tureckiej niespodziewanie uległo załamaniu na odcinku zajętym przez DP „Manastir” redif. Dżawid pasza, dowódca VI Korpusu dostał wiadomość, że DP „Üsküb” rozpoczęła odwrót. Próbował jeszcze powstrzymać natarcie serbskie swymi odwodami, jednak rychło sytuacja uległa dalszemu pogorszeniu. Artyleria turecka zaczęła słabnąć, natomiast ogień serbski był coraz silniejszy i celniejszy ${ }^{202}$. Poza tym, siłom „Driny”, wspartym potężnym ogniem artyleryjskim udało się około godziny 13.00 zająć strategicznie ważne wzgórze Zebrnjak (tur. Taş- Tepesi), będące głównym elementem tureckiej strategii obronnej i miejscem kwatery głównej VI Korpusu. Silny serbski ostrzał armatni zmusił rozlokowane tam oddziały osmańskie pierwszoliniowej 17 Dywizji nizam do bezładnego odwrotu $^{203}$. Wkrótce nastapiło ostateczne rozstrzygnięcie. Około godziny 14.00 zagrożone odcięciem i zniszczeniem, pozostałości DP „Manastir” i „Üsküb” zdecydowały się na odwrót. W tej sytuacji Zeki pasza rozkazał lewemu skrzydłu i centrum, tj. VI i VII Korpusowi oraz swej kawalerii odwrót spod Kumanova wzdłuż Pčinji w kierunku Skopje ${ }^{204}$. Niespodziewane zwycięstwo Serbów stało się faktem, a po godzinie 15.00 oddziały DP „Morava” (I) zajęły Kumanovo

\footnotetext{
197 Ibidem, s. 178.

198 Por. B. Ratković, M. Đurišić, S. Skoko, op. cit., s. 80- 81.

199 Ibidem, s. 81.

200 Ibidem, s. 81- 83.

201 Ibidem, s. 81.

202 Por. E. J. Erickson, op. cit., s. 180.

203 Ibidem, s. 180.

${ }^{204}$ Ibidem, s. 180.
} 
Klęska tureckiej Armii „Wardar” była zupełna. Pokonane oddziały VII i VI Korpusu cofały się w chaotycznym odwrocie w kierunku Skopje, a pozostałości V i reszta VI Korpusu do Štipu, Velesu i Monastiru ${ }^{205}$. Podczas odwrotu mało nie zginął sam Zeki pasza z rąk rozwścieczonych własnych żołnierzy, którzy winili go za klęskę. Oprócz żołnierzy, z Macedonii uciekała także masowo cywilna ludność turecka i wszyscy ci, którzy obawiali się nowych rządów, odwetu chrześcijan, żołnierskich gwałtów, rabunków i nadużyć, tylko niektórzy z Osmanów pozostali jeszcze w miastach i mniejszych miejscowościach ${ }^{206}$.

Nimb głównego zwycięzcy i pogromcy Turków w bitwie pod Kumanovem przypadł księciu Aleksandrowi I. Choć najistotniejsza rola operacyjna faktycznie przypadła generałowi Putnikowi, to fakt formalnego dowództwa Aleksandra umożliwił znakomite wykorzystanie ideologiczne tego zwycięstwa przez monarchię, ówczesny następca tronu zyskał sobie tytuł ,głównego wyzwoliciela Serbów”. Radomir Putnik i jego zastępca, generał Živojin Mišić (1855-1921) zostali nagrodzeni, obaj po bitwie zostali awansowani na najwyższy stopień w armii - stopień vojvody, tj. odpowiednika marszałka polnego ${ }^{207}$.

Ocena tego jednego z decydujących starć I wojny bałkańskiej i jego przebiegu jest niejednoznaczna. Początkowo przewagę mieli Turcy. Decyzja Zekiego paszy o ataku była jak najbardziej słuszna, bo oparta na założeniu uprzedzającego uderzenia, zanim jeszcze wszystkie siły serbskie biorące udział w operacji ostatecznie połączą się ze sobą i osiagną pełną gotowość operacyjną. Serbskie dowództwo miało słabą orientację $w$ przebiegu wydarzeń i przynajmniej przez pierwszy dzień starcia nie zdawało sobie sprawy z tego, że toczy walną bitwę z głównymi siłami wroga. Utrzymanie pola w pierwszej fazie bitwy zawdzięczają Serbowie przede wszystkim swoim dowódcom i żołnierzom liniowym, którzy stawili zacięty opór. Przełom nastąpił po dotarciu na pole bitwy 3 serbskich dywizji tyłowych Po odpowiednim przegrupowaniu sił serbskich stało się możliwe ich przejście do skutecznego kontrataku.

Na korzyść Serbów działał także stosunek sił, bo ich 1 Armia po dotarciu wszystkich wielkich jednostek, górowała liczebnie nad turecką. Natomiast dość wyrównana była liczba posiadanych dział i karabinów maszynowych.

Kolejnym czynnikiem, który na pewno nie pomógł żołnierzom tureckim w walce pod Kumanovem była amunicja dostarczona z Niemiec z firmy Deutsche Waffen und Munition Fabrik z Karlsruhe. Część żołnierzy tureckich strzelała drewnianymi pociskami, lub ślepymi, używanymi tylko ćwiczebnie ${ }^{208}$. Trudno powiedzieć, czy był to

205 Ibidem, s. 83.

${ }^{206}$ O schyłku i końcu panowania osmańskiego w Macedonii i tamtejszych stosunkach etnicznych, telewizja francuska nakręciła w 2005 roku interesujący miniserial fabularny „Ostatni bej Bałkanów” (Le Dernier Seigeur des Balkans), którego głównymi bohaterami są członkowie tureckiego rodu arystokratycznego z Goriški (tur. Goriçka), osiadłego tam od wieków.

207 P. Michalak, op. cit., s. 170.

208 Por. Turks had Wooden Bullets. Cartridges intended Only for Manoeuvres Were Sent to the Front, „The New York Times”, Nov. 27, 1912, http://query.nytimes.com/mem/archive-free/pdf?res=9902E60C1 E3AE633A2 57 C2A9679463960CF 
sabotaż czy pomyłka. Chyba jedynym lokalnym sukcesem, jaki odnieśli Turcy i to zupełnie gdzie indziej, a o którym pisze we wspomnianym artykule „New York Times” było odzyskanie miast Vučtrin (alb. Vushtrri) i Gnjilane (alb. Gnjilan) w Kosowie ${ }^{209}$.

\section{BILANS BITWY POD KUMANOVEM}

Po południu, 24 października 1912 roku, pokonane siły tureckie, zagrożone okrążeniem i zniszczeniem, zmuszone zostały do odwrotu, a zwycięscy Serbowie wkroczyli do Kumanova. Relacja „New York Timesa” z 25 października donosi o odwrocie sił tureckich i zajęciu przez Serbów nowych pozycji „pomiędzy Kumanovem a Üskübem”. Korespondent tejże gazety donosi o „wielkim zwycięstwie nad Turkami pod Kumanovem”. [Kara] Said pasza i Turcy mieli według jego relacji stracić „5 tysięcy żotnierzy, 12 dziat i bliżej nieustalona ilość amunicji"210. Wiadomości te wydają się jednak mocno nieścisłe. Możliwe, że amerykański korespondent połączył wiadomości dotyczące bitwy pod Kumanovem z tylko trochę późniejszymi dotyczącymi starć serbsko-tureckich pod Kočani i Kratovem. Nie można też całkiem wykluczyć pomyłki w osobach tureckich dowódców, tj. Saida paszy i Zeki paszy. Podana w tym newsie liczba utraconych przez Turków armat również wydaje się zbyt mała.

Obliczenia wzajemnych strat różnią się niekiedy dość znacznie. W tej uważanej za kluczową dla armii serbskiej bitwie Turcy mieli stracić 1200 poległych żołnierzy i około 3 tysiące rannych, ponadto 327 trafiło do niewoli. Straty serbskie były niemal dwukrotnie mniejsze i wyniosły, jak podają Aleksandar Jovičić i Mirosław Dymarski tylko 667 ludzi oraz 2 tysiące 380 rannych $^{211}$. Inne dane dla strony serbskiej podaje ostatnio Slavenko Terzić, który uważa, że w bitwie tej padło 687 do 1 tysiąca zabitych i 3208 żołnierzy serbskich zostało rannych, a 597 zaginęło $^{212}$.

Istnieją natomiast widoczne rozbieżności odnośnie strat tureckich. Według Richarda W. Halla i Philipa S. Jovetta, pod Kumanovem miało zginąc nie tylko 1200 żołnierzy osmańskich, lecz ogółem straty wyniosły aż 12000 żołnierzy, ponadto Turcy mieli utracić aż 98 dział, na posiadanych ogółem 164-190!213. Co ciekawe, taką samą liczbę strat podaje wspomniany S. Terzić, aczkolwiek sama liczba zabitych

209 Ibidem.

210 Por. Turks retreating to Uskub, op. cit.

211 Por. A. Jovičić, op. cit., s. 22; M. Dymarski, op. cit., s. 249.

212 Por. S. Terzić, Istorijski smisao Kumanovske bitke, http://www.pecat.co.rs/2010/11/istorijskismisao-kumanovske-bitke/

${ }^{213}$ Por. E. J. Erickson, op. cit., s. 180 (tamże autor powołuje się na dane R.W. Halla). Wspomniany już Erickson podaje, opierając się na źródłach osmańskich, że pod Kumanovem zabitych zostało 1200 żołnierzy, 3 tysiące odniosło rany, a 38 oficerów i 289 żołnierzy niższych stopniem zostało wziętych do niewoli. Turcy obliczyli natomiast straty Serbów na 1 tysiąc 127 zabitych żołnierzy i 3 tysiące 468 ludzi rannych na ogólną sumę strat 4, 5 tysiąca. Natomiast P. S. Jovett, przyjął dane wg R. W. Halla i liczbę 98 armat tureckich utraconych w bitwie, por. idem, s. 5. 
Turków miała wynosić według niego 2 tysiące ${ }^{214}$. Tak, czy inaczej - różnica między 1200 poległych pod Kumanovem, a stratami w łącznej wysokości aż 12000 jest bardzo duża.

Jeśli uznać za prawdziwe obliczenia strat na 1200 poległych żołnierzy tureckich i 667/687 do tysiąca żołnierzy serbskich, to w stosunku do deklarowanej rangi tego starcia i posiadanych sił, liczba poległych nie była zbyt wielka. Natomiast gdyby przyjąć za wiarygodny ów górny pułap poniesionych ogólnych strat żołnierskich Armii Wardaru, czyli 12000 żołnierzy i aż 98 armat, to bitwa mogłaby być dobrym memento dla przyszłych hekatomb Wielkiej Wojny i znacznie lepszym argumentem do decyzji o wycofaniu się Zekiego paszy w kierunku Velesu, Prilepu i Monastiru, tj. miejscami ponad $150 \mathrm{~km}$ dalej. Nie wydaje się jednak, by poziom strat tureckich pod samym Kumanovem był aż tak drastycznie wysoki. Najprawdopodobniej, bowiem Edward J. Erickson i Philip Jovett doliczyli do tego smutnego bilansu osmańskiego pod Kumanovem również bitwy pod Kočani i Kratovem.

\section{SYMULTANICZNE DZIAŁANIA WOJSK SERBSKICH}

Charakter działań pokazuje również, że tak naprawdę Turcy nie byli przygotowani do wojny z sojuszem bałkańskim aż na taką skalę i zupełnie go nie docenili. Przede wszystkim przez cały czas istniało zagrożenie okrążenia przez wojska czterech armii sojuszniczych poszczególnych sił osmańskich działających w izolowanych punktach oporu. Kolejne wielkie niebezpieczeństwo, to możliwość odcięcia linii zaopatrzenia pozostających w oddaleniu od głównych sił, skoncentrowanych na froncie europejskim w Tracji Wschodniej. Pewną poprawę sytuacji mogłyby przynieść posiłki z prowincji azjatyckich Imperium. Te jednak nie mogły się szybko pojawić w Macedonii, a potem już w ogóle nie było to możliwe.

Wpływ na wycofanie się Zekiego paszy mogła mieć również stale pogarszająca się sytuacja Turcji na frontach I wojny bałkańskiej. Tuż przed zakończeniem pierwszej wielkiej konfrontacji serbsko-tureckiej w Macedonii, 22-23 października, wojska osmańskie poniosły również bardzo dotkliwą klęskę w symultanicznej z Kumanovem bitwie pod twierdzą Kirk- Kilisse (bułg. Łozengrad, obecnie Kirklareli w Turcji) we Wschodniej Tracji z Bułgarami ${ }^{215}$. Wkrótce potem armia bułgarska przystąiła do oblężenia uważanego za twierdzę nie do zdobycia Adrianopola i zamkniętego tam

214 Por. S. Terzić, op. cit..

215 Zdobycie Kirk- Kilisse kosztowało Bułgarów 887 zabitych, ponad 4 tysiące rannych i 824 zaginionych. Straty tureckie wyniosły 1,5 tysiąca zabitych i 2-3 tysiące wziętych do niewoli. Szczególnie dotkliwa była jednak utrata znacznej ilości uzbrojenia i sprzętu wojskowego. Por. M. Dymarski, Konflikty, s. 254. Szczegółowe dane to: 150 tysięcy sztuk pocisków artyleryjskich, aż 120 tysięcy karabinów i kilka milionów sztuk amunicji strzeleckiej. Por J. Rubacha, op. cit., s. 257- 258. O tym teatrze I wojny bałkańskiej i wysiłku militarnym armii bułgarskiej, por. także A. Malinowski, op. cit., s. 130 i n. i T. Czekalski, Butgaria, s. 84- 88; S. J. Shaw, E.K. Shaw, op. cit., s. 450. 
50-60 tysięcznego garnizonu osmańskiego ${ }^{216}$. Zeki pasza mógł już tylko w założeniu bronić się w południowo-zachodniej części Macedonii i w razie zatrzymania się ofensywy serbskiej, czekać na przebicie się ewentualnych posiłków. Dalszy, bardzo szybki rozwój wydarzeń pokazał jednak, że całkowita klęska jego armii była nieunikniona, podobnie jak upadek panowania osmańskiego w Europie.

Dodatkowym czynnikiem wzmagającym obawę dowódców tureckich, także i Armii Wardaru, było niespodziewane wystąpienie zbrojne Grecji i postępy militarne armii greckiej, która przystąpiła do zajmowania Epiru, ale przede wszystkim Macedonii Egejskiej i realnie zagroziła Salonikom ${ }^{217}$. Grecy odnosili też w ciągu października - listopada 1912 roku widoczne sukcesy w Epirze i w Albanii (tu oblężenie Janiny i Korczy). Tak więc, posiadane przed wojną prowincje europejskie Imperium Osmańskiego, w stosunkowo krótkim czasie uległy ogromnej redukcji do rozmiarów kilku ważniejszych twierdz i miast. Wycofanie się w kierunku na Prilep i Monastir miało zapewne stworzyć dla Armii Wardaru nowy, znaczący ośrodek oporu, by wraz z garnizonem salonickim doczekać nadejścia posiłków z Bliskiego Wschodu.

Pierwotny plan przewidywał, że serbska 2 . Armia będzie starała się całkowicie odciąć od wschodu, tj. granicy bułgarskiej, możliwość odwrotu pobitych sił tureckich Zekiego paszy spod Kumanova, zniszczyć je lub przynajmniej zmusić do kapitulacji. Tu jednak wyłonił się nieoczekiwany problem. Bułgarski generał Georgi Todorow, dowódca 7. Dywizji Rilskiej, otrzymał od naczelnego dowództwa rozkaz szybkiego marszu w kierunku miasta Seres (tur. Serez) i jak najszybszego wkroczenia do Salonik ${ }^{218}$. Na prośbę cara Ferdynanda i sztabu bułgarskiego, dla realizacji zobowiązań sojuszniczych, 2. Armia serbska przez Krivą Palankę, Kjustendił i Gorną Dżumaję (od 1950 r. Błagojewgrad) została przerzucona pod Adrianopol i tam też wzięła udział $\mathrm{w}$ jego oblężeniu ${ }^{219}$. Nie znaczy to, że siły 2 . Armii zupełnie przestały walczyć z pokonanymi wojskami Zekiego paszy.

Zajęcie Kumanova i niewątpliwy, dość niespodziewany sukces Serbów nie oznaczał jeszcze końca zmagań o tę część terytorium macedońskiego. Jeszcze dniu 24 października stoczona została przez siły 2 . Armii bitwa pod Kočani. Turcy stracili tam łącznie 5 batalionów z 16. Dywizji nizam V. Korpusu Saida paszy, co pozwoliło

216 Por. T. Rawski, op. cit., s. 83; R. Rabka, op. cit., s. 206 (tamże skład jednostek garnizonu).

2178 listopada 1912 roku siły 7. Dywizji Rilskiej i greckiej 1. Dywizji weszły jednocześnie do Salonik. Jednak turecki dowódca obrony miasta skapitulował przed Grekami, a Bułgarzy zostali potraktowani tylko jak ,goście”. Ta sytuacja i zaistniały spór o miasto były widoczną zapowiedzią rychłego konfliktu między Bułgarią, a Grecją. Por. J. Rubacha, op. cit., s. 275.

218 Por. R. C. Hall, op. cit., s. 53.

219 Por. T. Rawski, op. cit., s. 86; J. Rubacha, op. cit., s. 258; A. Malinowski, op. cit., s. 233 i n. Obrona miasta dowodzona przez Szukriego paszę (tur. Şükrü Paşa), mimo zaciekłości kolejnych szturmów sił 3 wielkich dywizji bułgarskich, (łącznej obecności podczas oblężenia blisko 160 tysięcy żołnierzy bułgarskich i serbskich i niemal 480 dział), trwała od listopada 1912 aż do schyłku marca 1913 roku. 25 marca Szukri pasza po zaciętej i heroicznej obronie poddał Adrianopol Bułgarom 25 marca. Turecki dowódca był witany jak bohater wojenny w Sofii. O walkach o miasto por. szeroko J. Rubacha, op. cit., s. 285- 287; T. Czekalski, Butgaria, s. 85- 88. 
Serbom zająć Štip ${ }^{220}$. Dwa dni później, 26 października, doszło do bardzo istotnej bitwy pod Kratovem (na wschód od Kumanova), gdzie siły 2. Armii serbskiej pokonały po raz kolejny, (także w kilku towarzyszących starciach) wojska tegoż V. Korpusu ${ }^{221}$. Turcy mieli tam łącznie utracić aż 135 dział'22. Możliwe, że to właśnie pod Kočani i Kratovem stracili także owe 5 tysięcy ludzi, znane z relacji „The New York Timesa”. Utrata aż tylu armat różnego typu oznaczała istny pogrom. To także te sukcesy, oprócz zwycięstwa kumanovskiego, zmusiły Turków do dalszej defensywy, ewakuacji ze Skopje garnizonu zagrożonego zupełnym odcięciem od reszty pokonanej 3 . Armii, co pozwoliło na zajęcie miasta przez siły serbskie.

Część rozbitych wojsk osmańskich zmierzała w dół biegu Wardaru w kierunku broniących się jeszcze Salonik, natomiast inne, ocalałe lub nie biorące uprzednio udziału w walkach oddziały starały się odtworzyć linię obrony wokół Monastiru i zatrzymać tam Serbów ${ }^{223}$. Zapewne tych wydarzeń dotyczy relacja „New York Timesa”, datowana na 29 października o odwrocie części sił tureckich ze Skopje w kierunku Velesu $^{224}$. Pokonani żołnierze tureccy poddawali się oddziałom kawalerii serbskiej podążającej w stronę tego miasta i masowo porzucali broń. Serbowie mieli w trakcie tej kampanii zdobyć aż 123 działa tureckie 225 .

Kumanovo, a potem Kočani i inne lokalne starcia absolutnie nie oznaczały końca kampanii, co więcej, to dalszy jej ciąg okazał się rozstrzygający. Kolejna część sił serbskich, tj. dywizje „Morava” (I) i „Dunav” (I) przystąpiły do zajmowania kolejnych obszarów Macedonii Wardarskiej i z początkiem listopada 1912 roku uderzyły na Prilep (tur. Pirlep). Był to kluczowy punkt dla dalszej obrony tureckiej i dla utrzymania przez Osmanów tej części Macedonii. Pozostałe po walkach oddziały osmańskie zostały skoncentrowane na pobliskim obszarze gór Babuna, a zwłaszcza na przełęczach Prisad i Pletvar, które zamykały drogę do Prilepu od strony Velesu i Krivolaku ${ }^{226}$. Pasmo Babuny i jego obrona stało się swoistym ryglem terytorialnym do resztek panowania osmańskiego w Macedonii. Na północny wschód od Prilepu obszar ten był pozbawiony dróg, tak więc zachowanie obrony na przełęczach miało decydujące znacznie dla utrzymania tak Prilepu, jak i Monastiru, tym bardziej, że położony na zachód obszar Prilepsko Polje nie stanowił już dla ofensywy serbskiej żadnej przeszkody, a nawet pozwalał na dalsze rozwinięcie sił227. W dniach 3-5 listopada siłom serbskim niespodziewanie udało się przebić przez bronione przez Osmanów przełęcze Prisad i Pletvar i po lokalnej bitwie pod Alinci (tur. Alinça) zająć Prilep, co

${ }^{220}$ Por. J. Rubacha, op. cit., s. 259.

221 R.W. Hall, op. cit., s.

222 Por. Relacja „New York Timesa” z 4 listopada 1912 roku, http://query.nytimes.com/mem/archi ve-free/pdf?res=9005E0D8133CE633A25756C0A967D94639606CF.

${ }^{223}$ R.W. Hall, op. cit., s.; M. Dymarski, op. cit.

224 Por. Turks surrender to the Servians, „The New York Times”, Oct. 29, 1912, http://query.nytimes. $\mathrm{com} / \mathrm{mem} /$ archive-free/ pdf?res=9405E6061630E233A2575AC2A966909463960CF.

225 Ibidem.

${ }^{226}$ Por. T. Rawski, op. cit., s. 86.

227 Por. B. Ratković, M. Đurišić, S. Skoko, op. cit., s. 92- 93; M. Dymarski, op. cit., s. 250. 
zmusiło resztę sił tureckich do wycofania się do Monastiru. Mimo lokalnego sukcesu Turków, tj. pokonania przez oddziały VI. Korpusu części sił serbskich w dniu 4 listopada pod Kukurečani (tur. Kirçova), ich ogólna sytuacja nie wyglądała zbyt dobrze ${ }^{228}$.

Dalszy rozwój wydarzeń miał decydujące znaczenie dla dalszego losu kampanii, zapoczątkowanej pod Kumanovem i ostatecznie przesądził o utracie przez Osmanów Macedonii Wardarskiej. Najważniejszą rolę odegrała tu niezwykle zacięta bitwa o zdobycie Monastiru (14-18 listopada 1912). Na niekorzyść Osmanów działał też fakt zdobycia w dniu 8 listopada Salonik przez Greków, co zamykało siłom tureckim nie tylko ewentualną drogę odwrotu, ale i stworzenie nowego, znaczącego ośrodka oporu w Macedonii.

Kluczowym punktem osmańskiego oporu w walkach o Monastir stało się wzgórze Obljakov Vis i miejscowość Obljakovo (tur. Oblakova). W toku kilkudniowych bardzo krwawych i zaciętych walk, Turcy nie zdołali utrzymać swych pozycji, a atakujące siły serbskie dokonały przełamania ich obrony, co dopełniło ostatecznej klęski osmańskiej w zmaganiach o Macedonię. Bitwa o Monastir była najbardziej dotkliwa pod względem strat dla armii tureckiej, bo w walkach o to miasto zginęło aż od 10000 do 12000 żołnierzy tureckich, znacznie więcej, niż w walkach o Kumanovo. Zwycięscy Serbowie stracili około 4000 wojska, również znacznie więcej, niż w bitwie kumanovskiej229. Po klęsce pod Monastirem z liczącej jeszcze około 60000 żołnierzy (78 batalionów) po bitwie pod Kumanowem Armii Wardarskiej pozostało Osmanom już jedynie około 39000 wojska ${ }^{230}$. Wśród licznych poległych osmańskich znalazł się sam Fethi pasza, dowódca VII Korpusu ${ }^{231}$.

W rzeczywistości, więc, to późniejsze bitwy, Kratovo, Kočani, a zwłaszcza walki o Prilep i Monastir, ostatecznie dopełniły tego, co jedynie zapoczątkowało Kumanovo i udział księcia Aleksandra. Po tych bitwach, resztki wojsk VI Korpusu i innych jednostek osmańskich w odwrocie skierowały się ku Albanii i Epirowi, gdzie broniło się jeszcze kilka odizolowanych garnizonów osmańskich, a w ślad za nimi podążali Serbowie ${ }^{232}$.

Również i na innym, pomocniczym kierunku działań wojennych siły serbskie odniosły istotny sukces, tym ważniejszy, że okupiony stosunkowo niewielkim kosztem. Zgodnie z planem serbska Armia Ibarska, dowodzona przez generała M. Živkovicia miała skierować się na teren Sandżaku i opanować Novi Pazar, a następnie udać się w kierunku Kosovskiej Mitrovicy (alb. Mitrovicë). Atak sił serbskich na Novi Pazar rozpoczął się 24 października i zakończył pełnym powodzeniem. Serbowie bardzo dobrze wybrali obiekt swego uderzenia, bo na terenie Sandżaku nie było dużych regu-

228 Por. E. J. Erickson, op. cit., s. 186- 187.

229 Por. A. Jovičić, op. cit., s. 25; M. Dymarski, op. cit., s. 250. Natomiast E. J. Erickson podaje, że Osmanowie mieli stracić tam aż 20000 tysięcy żołnierzy.

${ }^{230}$ Por. E. J. Erickson, op. cit., s. 193.

${ }^{231}$ Por. R. W. Hall, op. cit., s. 52.

232 Szerzej na temat dalszych działań sił serbskich na obszarze Albanii i we współdziałaniu z armią Czarnogóry, por. M. Dymarski, op. cit., s. 250- 251. 
larnych sił tureckich. Opór miało stawić początkowo jedynie około 1,5 tysiąca miejscowych wyznawców islamu, uzbrojonych w karabiny różnego typu ${ }^{233}$, co nie mogło zatrzymać zwycięskiego marszu Serbów.

Po kilku dniach spędzonych w Novim Pazarze, 28 października 3. Armia serbska generała B. Jankovicia wraz z DP „Šumadija” (I) i DP „Morava” (II), podjęła dość szybki marsz na Kosovską Mitrovicę, którą zajęła 29 października ${ }^{234}$. Tam też spotkała się z forpocztą wschodniej grupy sił czarnogórskich. Zgrupowanie ibarskie nie było zbyt znaczące pod względem liczebności (25 tysięcy wojska, 36 dział), jednak grupy zbrojne złożone z Albańczyków i tureckich baszybuzuków oraz dosyć słabe garnizony osmańskie nie były w stanie zatrzymać zwycięskich Serbów, którzy zajęli znaczną część obszaru Kosowa i Metohiji. Wspomniany wyżej numer „New York Timesa” informuje, że Serbowie zdobyli 15 ,szybkostrzelnych dział” oraz 4 tysiące karabinów wraz z ogromną ilością amunicji" ${ }^{235}$. W drodze wzdłuż linii kolejowej Serbowie mieli przejać aż 98 dział polowych i 15 haubic (!) wraz z platformami kolejowymi przeznaczonymi do ich przewozu ${ }^{236}$. To także ukazywało rozmiar klęski tureckiej w prowincjach europejskich.

\section{PAMIĘĆ O BITWIE NA POCZĄTKU XX WIEKU I WSPÓŁCZEŚNIE}

Sukcesy militarne pierwszych dni wojny, a w szczególności zajęcie Skopje, Serbowie wykorzystali, jako istotny atut propagandowy. W dniu 3 listopada do zdobytego miasta uroczyście wkroczył król Piotr I witany przez następcę tronu, licznych polityków i wojskowych oraz tłumy mieszkańców w charakterze ,pierwszego władcy serbskiego, który wkroczył, jako wyzwoliciel po 500 latach do Skopje"237. W tym czasie serbska Skupština w Belgradzie wydała specjalną ustawę o inkorporacji zdobytych okręów Novi Pazar, Kosowo, Kumanovo, Skopje, Veles, Prizren i Dibra (Debar) do Królestwa Serbii.

Dla wielu mieszkańców Europy Zachodniej wybuch I wojny bałkańskiej oznaczał wzmożone zainteresowanie mało lub w ogóle nieznanym i egzotycznym regionem Bałkanów. Dzięki prasie i relacjom korespondentów pojawiły się bardzo obco i zarazem egzotycznie brzmiące nazwy miast i wsi serbskich, bułgarskich i greckich, a niektórzy mężczyźni nawet kupowali mapy i zaznaczali małymi choragiewkami postępy poszczególnych armii ${ }^{238}$. Marszowi armii serbskich i toczonym przez nie walkom

233 Ibidem, s. 249.

234 Ibidem, s. 250.

235 Por. Turks surrender, op. cit.

236 Ibidem.

237 Por. King Peter in Uskub. Entry into Old Servian Capital, "The New York Times”, Nov. 4, 1912, http:/query.nytimes.com/mem/archive-free/pdf?res=F5OC14FA38581378DDDAD0894D94B828DF1D 3.

238 O tym zjawisku, odbiciu zmagań wojen bałkańskich w niektórych tytułach prasowych we Francji i zainteresowaniu społecznym, por. W. Sajkowski, Pierwsza wojna bałkańska wedtug francuskie- 
towarzyszyli liczni korespondenci prasowi, między innymi „,The New York Timesa”. Znajdował się tam również korespondent gazety „Kijewskaja Mysl” Lejb Bronstein, później znany jako Lew Dawidowicz Trocki. Jego wspomnienia zostały wydane drukiem w Niemczech ${ }^{239}$. Echa bitwy kumanovskiej odbiły się nawet w Australii, być może zwłaszcza w środowisku diaspory serbskiej lub bułgarskiej, czego dowodem był niewielki artykuł opublikowany w gazecie „The Mercury” w mieście Hobart ${ }^{240}$.

Największym beneficjentem zwycięstwa pod Kumanovem, które zepchnęło w cień inne sukcesy serbskie tej wojny, okazał się książę Aleksander, od 1921 koronowany władca Królestwa Serbów, Chorwatów i Słoweńców, a od 1929 roku Królestwa Jugosławii. Ogromnego wsparcia udzieliły mu ówczesne media, w tym bardzo popularne, wysokonakładowe czasopismo „Politika”241. Przede wszystkim dzięki niemu powstał i utrwalił się ,mit Kumanova”, jako „,wielkiego zwycięstwa”, „,największej bitwy" tej wojny i samego Aleksandra, jako bardzo dobrego stratega i dowódcy. Kolejne rocznice bitwy kumanovskiej były uroczyście obchodzone w 1922 i 1932 , a w związku z nimi wydawano okolicznościowe publikacje i albumy, które początkowo sławiły Radomira Putnika i króla Aleksandra, a potem głównie Aleksandra ${ }^{242}$.

Na pamiątkę zwycięskiej bitwy pod Kumanovem i dla uczczenia poległych żołnierzy, na szczycie wzgórza Zebrnjak, tuż koło wsi Mlado Nagoričane (9 km od Skopje) zaczęto wznosić w latach 1934- 1937 pomnik i mauzoleum ${ }^{243}$. Zaprojektowany został przez belgradzkiego architekta Momira Korunovicia. Został on uroczyście odsłonięty 30 października 1937 roku w 25. rocznicę starcia ${ }^{244}$. U jego podnóża znajdują się groby 687 poległych żołnierzy 1 . Armii księcia Aleksandra. Pierwotnie monument był wysoki na 48, 5 metra, a z jego szczytu można było zobaczyć w pogodny dzień panoramę Skopje. W okresie międzywojennym pole bitwy było odwiedzane przez bardzo

go dziennika „Le Temps”, a zachodnioeuropejskie stereotypy dotyczqce ludów bałkańskich, „Balcanica Posnaniensia", t. XIX, 2012, s. 242 i n. Wydarzenia te znalazły również dość szeroki rezonans w prasie ukazującej się na ziemiach polskich pozostających pod zaborami i w kręgu ówczesnych działaczy politycznych i intelektualistów. Por. ostatnio istotne studium problemu: K. Stępnik, Wojny lat 1912-1913 w prasie polskiej. Korespondencje wojenne i komentarze polityczne, Lublin 2011, s. 12 i n.

239 Por. L. Trotzki, Die Balkankriege 1912- 1913, Mehring Verlag, Essen 1996; Vor hundert Jahren begann der 1. Balkankrieg- Das Vorspiel zum 1. Weltkrieg, http://syndykalismus.wordpress. com/2012/10/09/vor-hundert-jahren-begann-der-1-balkankrieg-d .

240 Por. The Battle of Kumanovo. Account form the Servian Side. ,, The Mercury” (Hobart, Wednesday, 30 October 1912, page 5), artykuł w zbiorach National Library of Australia, http://trove.nla.gov.au/ndp/ $\mathrm{del} / \mathrm{print} /$ ArticleJpg/10257118?print=y.

241 Por. ostatnio na ten temat P. Michalak, op. cit., s. 171.

242 Ibidem, s. 172 i n.

243 Por. S. V. Češmadžiski, Selo Orah-Suv Ora, http://www.docstoc.com/docs/95442735/Selo Orah--Suv Ora.

244 Por. M. Stančić, Zebrnjak ponovo miniraju, http://www.novosti/rs/vesti/naslovno/akuelno293. html:274860-Zebrnjak-ponovo-mi... Ostatnio na temat ideowego i propagandowego przesłania pomnika na Zebrnjaku, por. A. Đ. Kadijević, Odjeci Prvog balkanskog rata u srpskoj arhitekturi, [w:] Prvi balkanski rat 1912/1913. godine. Društveni i civilizacijni smisao (Povodom stogodišnjice oslobođenja Stare Srbije i Makedonije), urednik A. Rastović, Niš 2013, s. 138- 144. 
liczne wycieczki szkolne, a od 1937 roku Zebrnjak i stojący tam pomnik łącznie zobaczyło 142000 uczniów, w tym 54000 dziewczą ${ }^{245}$.

W maju 1942 roku żołnierze bułgarscy okupujący wówczas Macedonię Wardarską wysadzili $2 / 3$ pomnika w powietrze, a jego wysoka iglica legła w gruzach. Pozostała jedynie dolna, powoli niszczejąca $w$ następnych latach partia ${ }^{246}$. Decyzję o częściowej odbudowie podjęto w czasach Ludowej Federacyjnej Republiki Jugosławii w 1954 roku. Wnętrze pomnika jest udekorowane freskami autorstwa Živorada Nastasijevicia, jednego z utalentowanych artystów grupy Zograf. Dalszą konserwację i odbudowę dla uczczenia przyszłej, 100- rocznicy bitwy podjęto w 2004 roku dzięki decyzji Ministerstwa Kultury Republiki Macedonii, a bezpośrednim wykonawcą została firma „Granit”247. Do dziś jeszcze są także widoczne częściowo na byłym polu bitewnym, (zwłaszcza z powietrza) linie okopów serbskich i tureckich przebiegające koło dawnych, nieistniejących już obecnie wsi Manojlijski Rid, Srtevica, Gelinski i Prkinski Rid ${ }^{248}$.

Bitwa pod Kumanowem była jednym z wielu starć zbrojnych, które zadecydowały o sukcesie Serbów w czasie pierwszej wojny bałkańskiej, stała się jednak najważniejszym ich symbolem. Choć dawno przeminęła już identyfikująca się z nią monarchia Karađorđeviciów, to do niej odwoływały się liczne inicjatywy kulturalne, naukowe i uroczystości państwowe w Serbii i Macedonii, jakie miały miejsce w setną rocznicę wojen bałkańskich ${ }^{249}$. W ostatnim czasie zresztą nawiązanie do kumanowskiej bitwy nabrało nowego wymiaru. Dawniej była ona symbolem serbskiego sukcesu, obecnie serbscy politycy w swych wystąpieniach czerpią z niej inspirację do

245 Por. Č. Antić, Zebrnjak, „Politika”, 17.07. 2012, http://www.politika.rs/pogledi/ChedomirAnticZebrnjak1t. html

246 Por. M. Stančić, op. cit.

247 Ibidem.

248 Por. S. V. Češmadžiski, op. cit.

249 Por. m.in. Kumanovska bitka- Battle of Kumanovo- Kumanova Muharebesi, http://www.youtu be.com/watch? v=Ov51GBA2gvk; B. Ignjatović, Kumanovska bitka, http:/www.youtube.com/watch?v= pl3Ka\%aoC18; Bitka kod Kumanova, http://blog.b92.net/text21286/Bitka-kod-Kumanova/; Knjiga i film o Kumanovskoj bici, http://www.b92.net/kultura/vesti.php?nav_category=2688yyyy=2012\&mm=108\& $\mathrm{dd}=278$ nav id $=655405$.

Stogodišnjica Kumanovske bitke 2410 2012, http://www.youtube.com/watch?v=vtsSEP2Rk-A; Kod- 100 Godini Kumanovska bitka (Zebrnjak); http://www.youtube.com/watch?=04HFVd61zks; RTV Vojvodina- Vek od Kumanovske bitke, http://www.youtube.com/watch?v=tYDD-K3QWq4; V. Perunović, Serbian Celebration of Victory over Turks in Kumanovo Battle, http://www.youtube.com/watch?v=V83_1 zC6wBW.

Między innymi w maju 2012 roku miała miejsce w Belgradzie międzynarodowa konferencja polityków „Od wojny bałkańskiej do pokoju bałkańskiego” (Od balkanskog rata do balkanskog mira), a 28 października 2012 roku pole bitwy pod Kumanovem odwiedził prezydent Serbii, Tomislav Nikolić, wraz z premierem Ivicą Dačiciem i przedstawicielami rządu - Por. Nikolić i Dačić na Zebrnjaku kod Kumanova, http://www.kurir-info.rs/print/nikolic-na-zebrnjaku-kod-kumanova-clanak-48...; Nikolic: Feier des Jahrestags der Schlacht von Kumanovo- eine Botschaft des Friedens und Verständnisses, http:// voiceofserbia.org/de/content-nikolic-feier-des-jahrestags-der-schlacht-von- kum... 
nakreślenia przyszłej perspektywy integracji Serbii i pozostałych państw Bałkanów Zachodnich, a także Turcji z Unią Europejską ${ }^{250}$.

\title{
THE BATTLE OF KUMANOVO (23-24 OCTOBER 1912) THE ARMED FORCES OF THE PARTIES, OPERATIONS, MILITARY AND POLITICAL CONSEQUENCES
}

\author{
Summary
}

The battle of Kumanovo traditionally passes as the most important clash of the Serbian and the Ottoman armies in the first Balkan war. The analysis of the military potential of both parties to the conflict, the weapons used by both armies, the positioning of forces, the battle plans and their realizations made possible a new interpretation of the course of the battle and its real meaning. In the light of recent studies, as it turned out, the command of the first Serbian Army not only did not predict the fight to take place near Kumanovo, but it was also unaware of the military operations happening near Kumanovo until the end of the first day of the battle. The ultimate success of the Serbian Army in the battle came more as a result of a lucky coincidence and the actions of the commanding line officers, rather than conscious military operations of the Serbian command, which did not join in the battle until its final stage. As a result of the battle of Kumanovo, the Ottoman Vardar army commanded by Zeki Pasha, which was the strongest one at the site, indeed suffered large losses and was forced to retreat, however, it was not the ultimate defeat. The later battles of Kratovo and Kočani and especially of Prilep and Monastir proved to be decisive.

The myth of Kumanovo as a decisive battle of the war served as dynastic propaganda for the Karađorđević and namely, for the current heir to the throne, Aleksander, who formally, assumed command of the fighting troops. The myth was established, though, and also nowadays, the battle of Kumanovo is treated as a symbol of Serbian victory, as, among other things the ceremonies held in 2012 at the $100^{\text {th }}$ anniversary of the battle prove.

${ }^{250}$ Zob. przemówienie Ministra Spraw Zagranicznych Serbii Vuka Jeremicia na konferencji w maju 2012 r. - Jeremić, Zajednički obeležiti stogodišnjica Balkanskih ratovima, http://www.politika.rs/rubrike/ tema-dana-/Jeremic-Zajednicki-obeleziti-stogodisnjicu... 
